\title{
Highly Efficient Magnetic Phosphoric Acid Modified Defatted Chlorella Vulgaris Algae ( MDCV/Fe304) as a Novel Biosorbent for Methylene Blue Removal
}

\author{
Zeinab Salehi ( $\nabla$ zsalehy@ut.ac.ir) \\ University of Tehran \\ Sahar Naziri \\ University of Tehran
}

\section{Research}

Keywords: Chlorella vulgaris, Lipid extraction, Phosphoric acid modification, magnetic composite, Methylene blue biosorption

Posted Date: January 4th, 2021

DOI: https://doi.org/10.21203/rs.3.rs-136792/v1

License: (c) (i) This work is licensed under a Creative Commons Attribution 4.0 International License.

Read Full License 
Highly efficient magnetic phosphoric acid modified defatted Chlorella vulgaris algae $\left(\mathrm{MDCV} / \mathrm{Fe}_{3} \mathrm{O}_{4}\right)$ as a novel biosorbent for methylene blue removal

\author{
Sahar Naziri ${ }^{1}$, Zeinab Salehi ${ }^{2}$ \\ ${ }^{1}$ Department of Chemical Engineering, School of Chemical Engineering, College of Engineering, University of Tehran, Tehran, Iran \\ Corresponding author's email: zsalehy@ut.ac.ir
}




\section{Abstract \\ Background:}

A novel biosorbent based on defatted Chlorella vulgaris (DCV) as a by-product of the biofuel industry was considered as an economical and inexpensive biosorbent in the form of magnetic modified defatted Chlorella vulgaris (MDCV/Fe3O4) for methylene blue (MB) removal. The lipid extraction was performed on raw Chlorella vulgaris (RCV). Phosphoric acid was selected as a DCV modifier. During acid modification, the variables affecting the biosorption capacity and the residual algae such as temperature $\left(30-70{ }^{\circ} \mathrm{C}\right)$, the contact time of DCV with acid (3-9 hr), the concentration of acid (2-6 mol/L), and the ratio of acid volume to DCV (30-70 mL/g) were investigated and optimized using Minitab-18 software. The modified defatted Chlorella vulgaris (MDCV) was prepared by acidification of DCV under optimal conditions. $\mathrm{MDCV} / \mathrm{Fe}_{3} \mathrm{O}_{4}$ was prepared using the co-precipitation method for easy and low-cost separation of biosorbent. The XRD, FTIR, SEM, EDS, BET, and VSM analyses were performed to identify the structures and characteristics of $\mathrm{RCV}, \mathrm{DCV}, \mathrm{MDCV}$, and $\mathrm{MDCV} / \mathrm{Fe}_{3} \mathrm{O}_{4}$. Some experiments were designed using Minitab-18 software to investigate the effects of temperature $\left(5-45^{\circ} \mathrm{C}\right)$, contact time $(30-90 \mathrm{~min})$, biosorbent dosage (15-45 mg), initial concentration of MB (20-100 mg/L), and pH (5-9) on the biosorption capacity of $\mathrm{MDCV} / \mathrm{Fe}_{3} \mathrm{O}_{4}$. The kinetic, isothermal and thermodynamic parameters were investigated on $\mathrm{MDCV} / \mathrm{Fe}_{3} \mathrm{O}_{4}$.

\section{Results:}

The specific surface area of $\mathrm{MDCV} / \mathrm{Fe}_{3} \mathrm{O}_{4}$ was $25.20 \mathrm{~m}^{2} / \mathrm{g}$. RCV, DCV, and $\mathrm{MDCV} / \mathrm{Fe}_{3} \mathrm{O}_{4}$ had a crystalline structure and MDCV had an amorphous structure. The data were most consistent with Pseudosecond-order and Freundlich models. The maximum biosorption capacity of $\mathrm{MDCV} / \mathrm{Fe}_{3} \mathrm{O}_{4}$ was calculated in the amount of $32.44 \mathrm{mg} / \mathrm{g}$. According to the positive values of $\Delta \mathrm{G}$ and negative values of $\Delta \mathrm{H}(-46.56$ $\mathrm{kJ} / \mathrm{mol})$ and $\Delta \mathrm{S}(-0.17 \mathrm{~kJ} / \mathrm{mol} . \mathrm{K})$, the biosorption of $\mathrm{MB}$ on $\mathrm{MDCV} / \mathrm{Fe}_{3} \mathrm{O}_{4}$ was non-spontaneous, exothermic with a decrease in irregularity.

\section{Conclusions:}

In this study, $\mathrm{MDCV} / \mathrm{Fe}_{3} \mathrm{O}_{4}$ was applied as the $\mathrm{MB}$ biosorbent. Modifications such as lipid extraction, phosphoric acid modification and magnetization improved this biosorbent in its biosorption capacity and separation. Data were optimized in the acid modification and MB biosorption steps. Comparison of the characteristics of $\mathrm{MDCV} / \mathrm{Fe}_{3} \mathrm{O}_{4}$ with unmodified species confirmed its high efficiency. Kinetic, isothermal and thermodynamic studies were also performed.

\section{Keywords:}


Chlorella vulgaris, Lipid extraction, Phosphoric acid modification, magnetic composite, Methylene blue biosorption

\section{Background}

Water is one of the main human needs that the development of urbanization and industry has polluted. Among organic pollutants, dyes are one of the important toxic with destructive effects, causing global attentions [1]. They have negative influences on the health of aquatic organisms and the passage of light into the water for plants' photosynthesis. In addition, they are very carcinogenic due to their aromatic structure, which poses a serious threat to human and animal health [2]. Artificial dyes are used in various industries such as textiles, plastics, foods, medicines, etc. [3]. Methylene blue (MB) is a cationic dye with detrimental effects on organisms over a short time [4]. It has morbidities such as eye irritation, headache, nausea, dizziness, and excessive sweating [5]. Therefore, the treatment of wastewater containing this dye is very significant due to its harmful effects.

Hitherto, various physical and chemical methods such as filtration, coagulation, flocculation, irradiation, oxidation, catalytic ozonation, etc, have been used to separate organic pollutants from effluents [6-11]. Environmental hazards, high operating costs, more time consuming, and requiring special expensive equipment are some of the disadvantages of these methods [12]. So, it is important to develop efficient, inexpensive, environmentally friendly, and high-efficiency methods.

The biosorption methods using biochars due to environmental compatibility, non-toxicity, low price, availability, and abundance are suitable for removing organic pollutants [13]. Some studies have suggested the use of biosorbents such as banana, cucumber, and potato peel [14], sago [15], leaves [16], rice husk [17], egg shell [18], and diverse algae such as Sargassum dentifolium, Ulva fasciata [19], Chlorella pyrenoidosa [20], Scenedesmus [21], and Spirulina [22]. These biosorbents are very efficient and inexpensive for the removal of organic pollutants from industrial effluents. However, the separation of these biosorbents is difficult and costly. Therefore, research was done on magnetizing the adsorbents as a cheap, effective, and easy separable material [23].

Chlorella vulgaris is biomass with high potential in biofuel production and as a by-product in the biofuel industry can be used for adsorbing many urban, industrial, and agricultural pollutants such as heavy metals, dyes, and pharmaceutical pollutants. This algae grows rapidly and its 
structure is resistant to adverse conditions. They are also a source of substances such as lipids, carbohydrates, proteins, vitamins, pigments, and minerals. Growth conditions such as limited nitrogen and phosphorus sources, high levels of carbon dioxide, light intensity and temperature increase the level of lipids and starches [24]. The fatty acids in polar lipid cell membranes and non-polar lipids, as energy sources, are used in the biodiesel production process and directly affect its quality [25].

Some researchers have shown that the extraction of lipids from algae increases the specific surface area and its biosorption capacity [26, 27]. On the other hand, there are studies on the use of sulfuric acid, hydrochloric acid, phosphoric acid, boric acid, etc, as a pretreatment of algae to increase biosorption capacity [28, 29].

One of the important issues is the efficient and low-cost separation of the biosorbents after the biosorption process. For this purpose, there are some studies on magnetic biological materials from different sources such as magnetic Sargassum horneri [30], magnetic Cymopolia barbata [31], and magnetic activated carbon [32].

In this study extraction of the lipid from raw Chlorella vulgaris (RCV) and modification of defatted Chlorella vulgaris (DCV) was carried out to gain further MB biosorption. Then it was subjected to an acid modification to increase the specific surface area of DCV. Another goal is magnetizing the modified defatted Chlorella vulgaris (MDCV) for easy and low-cost separation. In the acid treatment step, the variables affecting the MDCV biosorption capacity and residual MDCV were modeled by Minitab-18 software, using the response surface methodology (RSM). The magnetic modified defatted Chlorella vulgaris $\left(\mathrm{MDCV} / \mathrm{Fe}_{3} \mathrm{O}_{4}\right)$ was prepared as the final biosorbent. In the end, the effect of variables on the biosorption capacity of $\mathrm{MDCV} / \mathrm{Fe}_{3} \mathrm{O}_{4}$, was considered and modeled by Minitab-18 software. Finally, kinetic, isotherm, and thermodynamic parameters were studied.

\section{Results and discussion}

\section{Phosphoric acid treatment and optimization of parameters}

In order to optimize variables of acid treatment, the experimental results of the proposed levels are reported in Table 1. Also, multiple regression analysis of experimental data with $95 \%$ probability 
has been reported in Equations 1-2. Ineffective variables were removed to increase the suitability of the models with experimental data [33].

Table (1) - Experimental results from CCD proposed levels

\begin{tabular}{|c|c|c|c|c|c|c|}
\hline Run no. & $\mathrm{X}_{1}, \mathrm{~T}$ & $\mathrm{X}_{2}, \mathrm{t}$ & $\mathrm{X}_{3}, \mathrm{C}_{\mathrm{A}}$ & $\mathrm{X}_{4}, \mathrm{~V} / \mathrm{W}$ & $\mathrm{Y}_{1}, \mathrm{q}_{\mathrm{MDCV}}$ & $\mathrm{Y}_{2}, \mathrm{RP}_{\mathrm{MDCV}}$ \\
\hline 1 & -1 & -1 & -1 & -1 & 8.2250 & 56.5 \\
\hline 2 & 1 & -1 & -1 & -1 & 9.1465 & 45.5 \\
\hline 3 & -1 & 1 & -1 & -1 & 9.8998 & 52.5 \\
\hline 4 & 1 & 1 & -1 & -1 & 10.6434 & 31.0 \\
\hline 5 & -1 & -1 & 1 & -1 & 10.4720 & 52.5 \\
\hline 6 & 1 & -1 & 1 & -1 & 8.8975 & 22.5 \\
\hline 7 & -1 & 1 & 1 & -1 & 9.3889 & 46.5 \\
\hline 8 & 1 & 1 & 1 & -1 & 7.8629 & 10.0 \\
\hline 9 & -1 & -1 & -1 & 1 & 6.8480 & 53.5 \\
\hline 10 & 1 & -1 & -1 & 1 & 8.2671 & 49.5 \\
\hline 11 & -1 & 1 & -1 & 1 & 7.7110 & 57.5 \\
\hline 12 & 1 & 1 & -1 & 1 & 9.7640 & 30.0 \\
\hline 13 & -1 & -1 & 1 & 1 & 10.4203 & 45.5 \\
\hline 14 & 1 & -1 & 1 & 1 & 10.5270 & 20.5 \\
\hline 15 & -1 & 1 & 1 & 1 & 9.9386 & 51.5 \\
\hline 16 & 1 & 1 & 1 & 1 & 10.6725 & 9.5 \\
\hline 17 & -1 & 0 & 0 & 0 & 9.5086 & 50.5 \\
\hline 18 & 1 & 0 & 0 & 0 & 11.6263 & 23.0 \\
\hline 19 & 0 & -1 & 0 & 0 & 11.3029 & 52.0 \\
\hline 20 & 0 & 1 & 0 & 0 & 11.1090 & 46.0 \\
\hline
\end{tabular}




\begin{tabular}{lllllll}
\hline 21 & 0 & 0 & -1 & 0 & 11.4420 & 51.0 \\
22 & 0 & 0 & 1 & 0 & 11.9916 & 46.5 \\
23 & 0 & 0 & 0 & -1 & 12.8031 & 49.5 \\
24 & 0 & 0 & 0 & 1 & 12.4863 & 47.0 \\
25 & 0 & 0 & 0 & 0 & 12.7223 & 48.0 \\
26 & 0 & 0 & 0 & 0 & 12.6818 & 48.0 \\
27 & 0 & 0 & 0 & 0 & 12.8035 & 47.5 \\
\hline
\end{tabular}

$Y_{1}=-5.02+0.4863 X_{1}+2.047 X_{2}+0.504 X_{3}-0.1110 X_{4}-0.004711 X_{1}^{2}-0.1384 X_{2}^{2}-$

$0.01156 X_{1} X_{3}+0.000898 X_{1} X_{4}-0.0832 X_{2} X_{3}+0.01603 X_{3} X_{4}$

$Y_{2}=3.97+2.433 X_{1}+1.819 X_{2}+2.041 X_{3}-0.02264 X_{1}^{2}-0.0599 X_{1} X_{2}-0.1086 X_{1} X_{3}$

ANOVA results of recent regression are reported in Table 2. The calculated Fisher distributions of both models are greater than their critical values. Also, the P-values of them are less than 0.05. Therefore, the compatibility of the models with data is proven. The adjusted determination coefficients of models $Y_{1}$ and $Y_{2}$ are $91.34 \%$ and $96.14 \%$, respectively. So, it can be concluded that no other effective variable has been ignored [33].

Table (2) - ANOVA of the quadratic models of the MDCV biosorption capacity and residual MDCV

\begin{tabular}{|c|c|c|c|c|c|c|c|c|}
\hline Response & $\begin{array}{l}\text { Variation } \\
\text { source }\end{array}$ & $\mathrm{df}$ & SS & MSS & $\mathrm{F}_{\text {calc }}$ & $\overline{F_{c}}$ & $\mathrm{P}$-value & $\mathrm{R}_{\mathrm{adj}}^{2}$ \\
\hline \multirow{3}{*}{$\begin{array}{c}\text { MDCV biosorption } \\
\text { capacity, } \mathrm{Y}_{1}\end{array}$} & Regression & 10 & 71.07 & 7.10 & 28.43 & 2.49 & 0.00 & $91.34 \%$ \\
\hline & Error & 16 & 4.00 & 0.25 & - & - & - & - \\
\hline & Total & 26 & 75.0778 & - & - & - & - & - \\
\hline \multirow[t]{3}{*}{ Residual MDCV, $\mathrm{Y}_{2}$} & Regression & 6 & 4863.95 & 810.66 & 108.85 & 2.60 & 0.00 & $96.14 \%$ \\
\hline & Error & 20 & 148.95 & 7.45 & - & - & - & - \\
\hline & Total & 26 & 5012.91 & - & - & - & - & - \\
\hline
\end{tabular}


According to Table 3, the P-values of all coefficients of the effective variables in $\mathrm{Y}_{1}$ analysis is less than 0.05. Since the coefficients of interactions of $X_{2}$ and $X_{4}$ with other variables are significant, they can not be ignored. Regarding the response of $Y_{2}$, all variables except $X_{4}$ are significant [33].

Table (3) - Estimated regression coefficients for the quadratic models of the MDCV biosorption capacity and residual MDCV

\begin{tabular}{|c|c|c|c|c|c|c|c|c|}
\hline \multirow[t]{2}{*}{ Terms } & \multicolumn{2}{|c|}{ Uncoded coefficient } & \multicolumn{2}{|c|}{$\begin{array}{c}\text { The standard error of } \\
\text { the coefficient }\end{array}$} & \multicolumn{2}{|c|}{ t-value } & \multicolumn{2}{|c|}{ P-value } \\
\hline & $Y_{1}$ & $Y_{2}$ & $Y_{1}$ & $Y_{2}$ & $Y_{1}$ & $Y_{2}$ & $\mathrm{Y}_{1}$ & $\mathrm{Y}_{2}$ \\
\hline constant & -5.02 & 3.97 & 0.177 & 0.910 & 70.03 & 53.19 & 0.000 & 0.000 \\
\hline $\mathrm{X}_{1}$ & 0.4863 & 2.433 & 0.118 & 0.643 & 2.35 & -19.43 & 0.032 & 0.000 \\
\hline $\mathrm{X}_{2}$ & 2.047 & 1.819 & 0.118 & 0.643 & 1.36 & -5.48 & 0.193 & 0.000 \\
\hline $\mathrm{X}_{3}$ & 0.504 & 2.041 & 0.118 & 0.643 & 3.88 & -10.54 & 0.001 & 0.000 \\
\hline $\mathrm{X}_{4}$ & -0.1110 & - & 0.118 & - & -0.33 & - & 0.744 & - \\
\hline$X_{1}^{2}$ & -0.004711 & -0.02264 & 0.274 & 1.11 & -6.88 & -8.13 & 0.000 & 0.000 \\
\hline $\mathrm{X}_{2}^{2}$ & -0.1384 & - & 0.274 & - & -4.55 & - & 0.000 & - \\
\hline $\mathrm{X}_{1} \mathrm{X}_{2}$ & - & -0.0599 & - & 0.682 & - & -5.27 & - & 0.000 \\
\hline $\mathrm{X}_{1} \mathrm{X}_{3}$ & -0.01156 & -0.1086 & 0.125 & 0.682 & -3.70 & -6.37 & 0.002 & 0.000 \\
\hline $\mathrm{X}_{1} \mathrm{X}_{4}$ & 0.000898 & - & 0.125 & - & 2.87 & - & 0.011 & - \\
\hline $\mathrm{X}_{2} \mathrm{X}_{3}$ & -0.0832 & - & 0.125 & - & -3.99 & - & 0.001 & - \\
\hline $\mathrm{X}_{3} \mathrm{X}_{4}$ & 0.01603 & - & 0.125 & - & 5.13 & - & 0.000 & - \\
\hline
\end{tabular}

Based on Equations 1-2, $Y_{1}$ is a second-order function of $X_{1}$ and $X_{2}$. Growing of $X_{3}$ increases $\mathrm{Y}_{1}$ and $\mathrm{X}_{4}$ is almost ineffective. $\mathrm{Y}_{2}$ increases by enhancement of $\mathrm{X}_{1}, \mathrm{X}_{2}$, and $\mathrm{X}_{3}$. Also, $\mathrm{X}_{4}$ is 
completely ineffective. Therefore, it is important to determine the optimal values of variables to maximize the amounts of $Y_{1}$ and $Y_{2}$ to achieve the maximum biosorption capacity in economic conditions. The optimal values of the recent factors are reported in Table 4. The composite desirability of this optimization is 0.95 .

Table (4) - Optimized factors affecting MDCV biosorption capacity and residual MDCV

\begin{tabular}{|c|c|c|c|c|c|c|}
\hline \multicolumn{4}{|c|}{ Optimized factor } & \multicolumn{2}{|c|}{ Optimized response } & \multirow{3}{*}{$\begin{array}{l}\text { Composite } \\
\text { desirability }\end{array}$} \\
\hline $\mathrm{X}_{1}$ & $\mathrm{X}_{2}$ & $\mathrm{X}_{3}$ & $\mathrm{X}_{4}$ & $\mathrm{Y}_{1}$ & $\mathrm{Y}_{2}$ & \\
\hline $\begin{array}{c}\text { Temperature } \\
\left({ }^{\circ} \mathrm{C}\right)\end{array}$ & $\begin{array}{l}\text { Contact } \\
\text { time } \\
\text { (hr) }\end{array}$ & $\begin{array}{l}\text { The } \\
\text { concentration of } \\
\text { phosphoric acid } \\
\left.\text { (mol. } \mathrm{L}^{-1}\right)\end{array}$ & $\begin{array}{l}\text { The ratio of acid } \\
\text { volume to DCV } \\
\quad\left(\mathrm{mL} . \mathrm{g}^{-1}\right)\end{array}$ & $\begin{array}{l}\text { MDCV } \\
\text { biosorption } \\
\text { capacity } \\
\left(\mathrm{mg} \cdot \mathrm{g}^{-1}\right)\end{array}$ & $\begin{array}{l}\text { Residual } \\
\text { MDCV } \\
(\%)\end{array}$ & \\
\hline 47.3 & 6.27 & 2 & 30 & 12.61 & 55.80 & 0.95 \\
\hline
\end{tabular}

DCV was treated with phosphoric acid under optimized conditions, then it was used as a biosorbent for more experimental results. The experimental data were consistent with the predicted responses. So, optimized MDCV is used in the magnetization stage.

\section{Biosorbent characterization}

\section{X-Ray Diffraction (XRD)}

The XRD analysis of RCV, DCV, MDCV, and $\mathrm{MDCV} / \mathrm{Fe}_{3} \mathrm{O}_{4}$ are shown in Fig. 1. In the analysis of $\mathrm{RCV}$, the peaks located in the range of $2 \theta, 23.1,29.5,36,39.5,43.2,47.7,48.6$ and 57.5 are attributed to the reflections of (012), (104), (110), (113), (202), (018), (116) and (122) respectively. They represent the magnesium calcite $\left(\left(\mathrm{Mg}_{0.03} \mathrm{Ca}_{0.97}\right)\left(\mathrm{CO}_{3}\right)\right)$ with the rhombohedral crystal structure in RCV [34]. It is also found in DCV. The plated distances in these two samples are almost the same [35]. The chart of MDCV has no sharp peaks, so its structure is amorphous. In this diagram, the peaks related to magnesium calcite have been removed. In the analysis of $\mathrm{MDCV} / \mathrm{Fe}_{3} \mathrm{O}_{4}$, peaks in the range of $2 \theta, 30.1,35.5,43.1,53.5,57.1$ and 62.7 related to reflections (220), (311), (400), (422), (511) and (440) which are shown the presence of iron oxide particles 
$\left(\mathrm{Fe}_{3} \mathrm{O}_{4}\right)$. Therefore, it can be concluded that the cubic crystal structure of iron oxide is well-formed $[32,36]$.

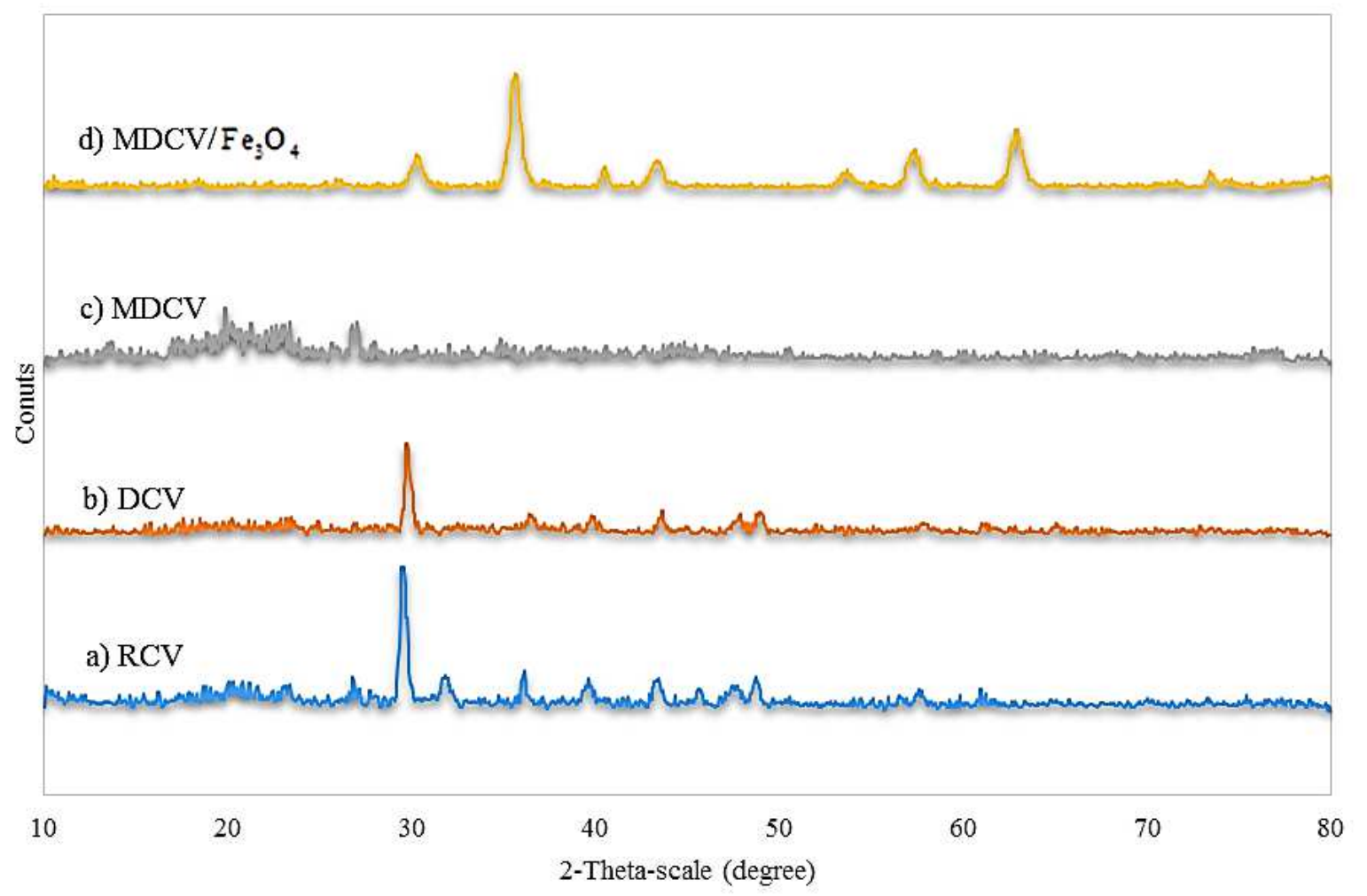

Figure (1) - XRD analysis for a) RCV, b) DCV, c) MDCV and d) $\mathrm{MDCV} / \mathrm{Fe}_{3} \mathrm{O}_{4}$

\section{Fourier Transform Infrared (FTIR)}

The results of FTIR analysis for $\mathrm{RCV}, \mathrm{DCV}, \mathrm{MDCV}$, and $\mathrm{MDCV} / \mathrm{Fe}_{3} \mathrm{O}_{4}$ are shown in Fig. 2. In all samples, the broad peak was observed in the range of $3400 \mathrm{~cm}^{-1}$. It shows the tensile vibrations of the hydroxyl bond $(\mathrm{O}-\mathrm{H})$, the amide groups $(\mathrm{N}-\mathrm{H})$, and the presence of the water molecules [29]. The peaks around $2926 \mathrm{~cm}^{-1}$ are associated with symmetrical and asymmetric tensional vibrations $\mathrm{C}-\mathrm{H}$ in aliphatic groups such as $\mathrm{CH}, \mathrm{CH}_{2}$, and $\mathrm{CH}_{3}$ [29]. The intensity of this peak is highest in RCV and almost the same in other samples. In RCV, a peak was observed in $2855 \mathrm{~cm}^{-1}$ , indicating $\mathrm{CH}_{2}$ and $\mathrm{CH}_{3}$ bonds in fatty acids. It confirms the presence of lipids in the structure of RCV that was removed after the lipid extraction process due to the removal of fatty acids [37]. The peak of $1730 \mathrm{~cm}^{-1}$ in RCV indicates tractions in carbonyl ester groups. It was removed by lipid extraction. Then, by acidification and magnetization, two peaks were formed again in the range of 
$1730 \mathrm{~cm}^{-1}$ and $1726 \mathrm{~cm}^{-1}$, which are due to the formation of carboxyl groups. The peaks in the range of $1650 \mathrm{~cm}^{-1}$ for all samples are related to the presence of $\mathrm{C}=\mathrm{O}$ an amide (I) of proteins and the carboxyl functional groups. The peaks in $1549 \mathrm{~cm}^{-1}, 1540 \mathrm{~cm}^{-1}, 1537 \mathrm{~cm}^{-1}$, and $1535 \mathrm{~cm}^{-1}$ related to $\mathrm{RCV}, \mathrm{DCV}, \mathrm{MDCV}$ and $\mathrm{MDCV} / \mathrm{Fe}_{3} \mathrm{O}_{4}$ respectively, indicate the presence of amide (II) of proteins. Peaks in the region of $1400 \mathrm{~cm}^{-1}$ are associated with $\mathrm{C}-\mathrm{H}$ bonds of lipids and proteins. The peaks in the region of $1260 \mathrm{~cm}^{-1}$ are related to $\mathrm{C}=\mathrm{O}$ bonds in carbonyl amide (II) of proteins and $\mathrm{P}=\mathrm{O}$ nucleic acid, phosphoryl, and phosphorylate groups. The intensities of these peaks are almost the same in all samples and indicate the preservation of these groups during the process. Also, wide peaks are observed in the range of $1200-900 \mathrm{~cm}^{-1}$, which is related to the C-O-C and C-Obonds present in carbohydrates and polysaccharides [37, 38]. Similar results have been reported by Kristina Maliutina et al. [39]. In RCV and DCV, peaks in $871 \mathrm{~cm}^{-1}$ and $875 \mathrm{~cm}^{-1}$ are observed respectively, which are related to the presence of $\mathrm{CO}_{3}^{2-}$ mineral compounds such as carbonates. In general, small peaks in the wavelength regions below $600 \mathrm{~cm}^{-1}$ are related to the tensile vibrations of organic and mineral halogen compounds such as $\mathrm{KCl}$ [40]. About the sample of $\mathrm{MDCV} / \mathrm{Fe}_{3} \mathrm{O}_{4}$, a wide peak is observed in the region of $571 \mathrm{~cm}^{-1}$, which indicates the $\mathrm{Fe}-\mathrm{O}$ vibrations, so the magnetic property of this sample is confirmed [32]. 


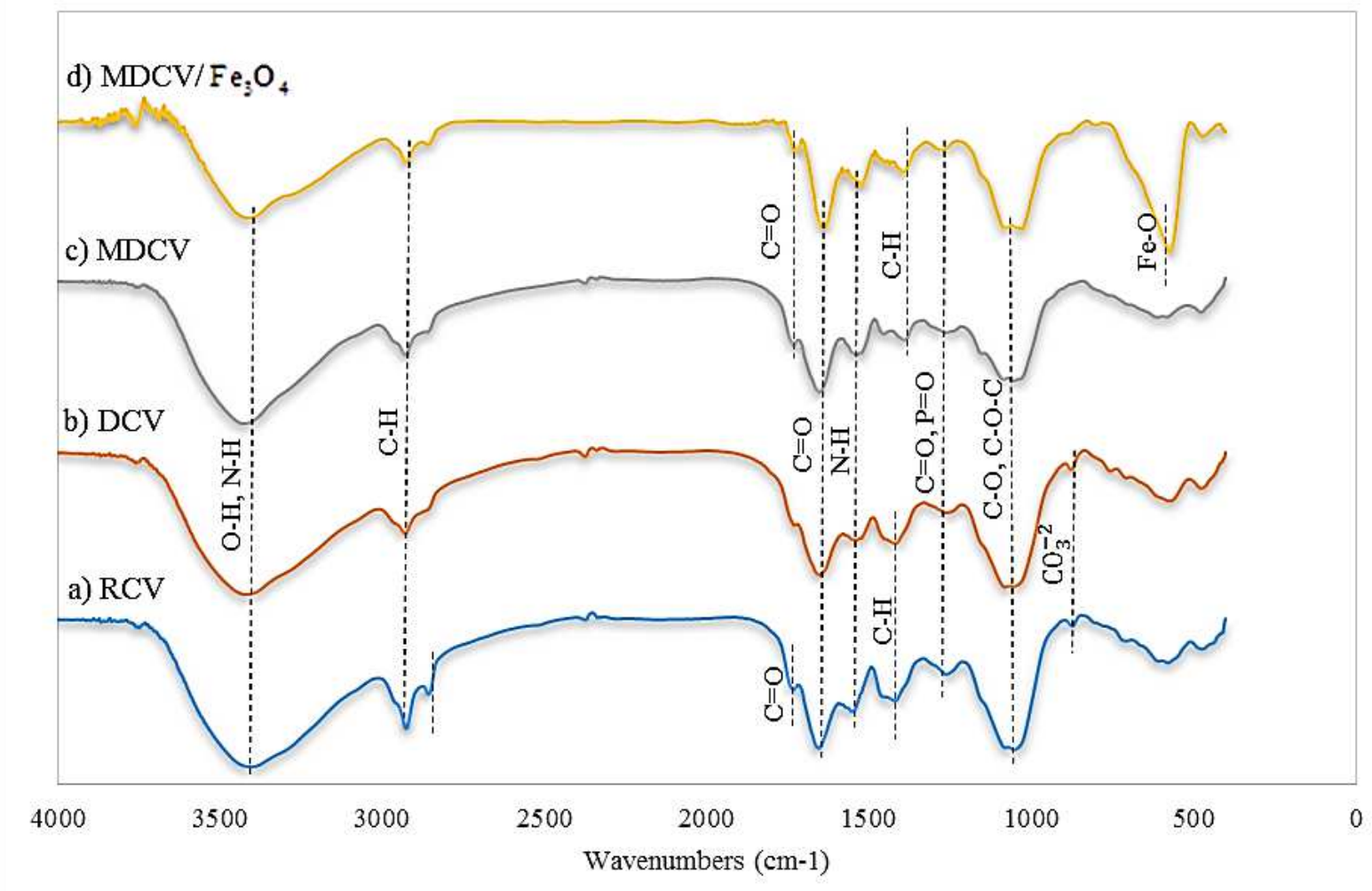

Figure (2) - FT-IR analysis for a) RCV, b) DCV, c) MDCV, and d) $\mathrm{MDCV} / \mathrm{Fe}_{3} \mathrm{O}_{4}$

\section{Scanning Electron Microscopy (SEM)}

The results of SEM analysis of RCV, DCV, MDCV, and $\mathrm{MDCV} / \mathrm{Fe}_{3} \mathrm{O}_{4}$ can be seen on the scale of $1 \mu \mathrm{m}$ and $200 \mathrm{~nm}$ in Fig. 3. As shown in Fig. 3a, the crystalline structure of the RCV is heterogeneous. According to Fig. 3b, no significant changes in algae structure occurred after lipid extraction. Chloroform and methanol can enter cell tissue without serious damages to the cell walls [41]. Based on Fig. 3c, phosphoric acid modification has caused severe structural changes. The crystalline structure of DCV has been transformed into an amorphous structure with a uniform and relatively homogeneous surface. Also, the particle size has increased compared to the previous ones. The formation of cavities and bulges on the surface of MDCV is an important factor in increasing the biosorption of dye pollutants [41, 42]. Fig. 3d shows the uniform coverage of the MDCV surface by iron oxide particles and the formation of a spherical crystalline structure [43]. 


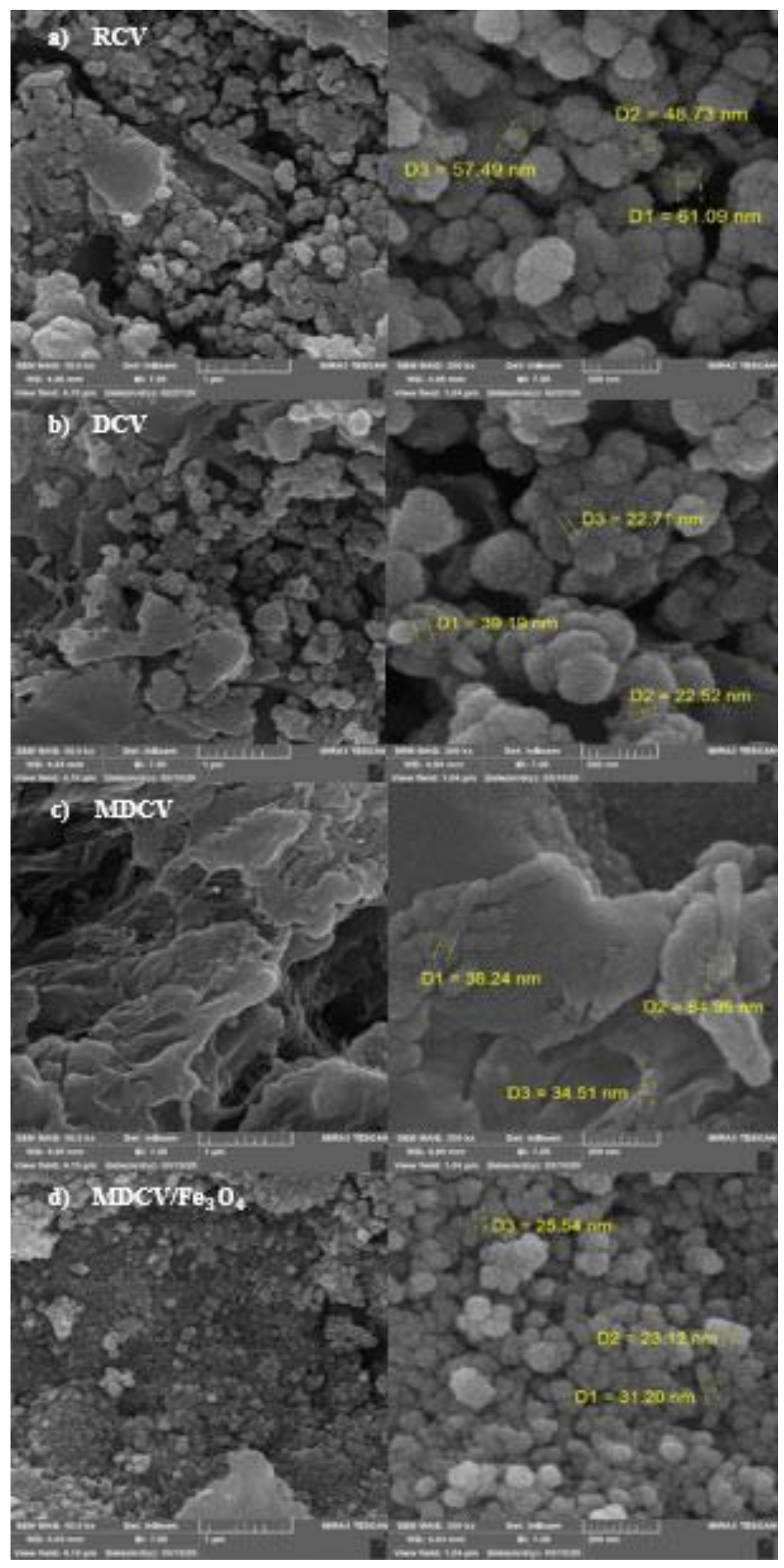

Figure (3) - SEM analysis for a) RCV, b) DCV, c) MDCV, and d) MDCV/Fe $e_{3} \mathrm{O}_{4}$ 


\section{Energy-Dispersive X-ray Spectroscopy (EDS)}

The EDS analysis was performed to obtain the elements of RCV, DCV, MDCV, and $\mathrm{MDCV} / \mathrm{Fe}_{3} \mathrm{O}_{4}$ that is shown in Fig. 4. Percentages of elements are reported in Table 5. The highest weight percentages in RCV and DCV are related to carbon and oxygen. Other elements such as nitrogen, sodium, magnesium, aluminum, calcium, phosphorus, sulfur, chlorine, potassium, and silicon are also found with a lower weight. According to the results, after magnetization, about $38 \%$ of the weight of $\mathrm{MDCV} / \mathrm{Fe}_{3} \mathrm{O}_{4}$ is related to the iron elements. Therefore, the weight ratio of the MDCV: $\mathrm{Fe}_{3} \mathrm{O}_{4}(1: 1)$ is almost confirmed.

Table (5) - Elemental composition of a) RCV, b) DCV, c) MDCV, and d) MDCV/Fe $e_{3} O_{4}$

\begin{tabular}{|c|c|c|c|c|}
\hline \multirow[t]{2}{*}{ Element } & \multicolumn{4}{|c|}{ Weight percentage (\%) } \\
\hline & $\mathrm{RCV}$ & $\mathrm{DCV}$ & MDCV & $\mathrm{MDCV} / \mathrm{Fe}_{3} \mathrm{O}_{4}$ \\
\hline $\mathrm{C}$ & 40.76 & 47.1 & 49.4 & 18.12 \\
\hline $\mathrm{N}$ & 10.65 & 13.38 & 17.83 & 7.41 \\
\hline $\mathrm{O}$ & 34.95 & 30.43 & 29.3 & 35.26 \\
\hline $\mathrm{Na}$ & 1.14 & 0.7 & 1.08 & 0.21 \\
\hline $\mathrm{Mg}$ & 0.67 & 0.65 & - & - \\
\hline $\mathrm{Al}$ & 0.26 & 0.31 & - & - \\
\hline $\mathrm{Si}$ & 1.02 & 0.54 & 1.29 & 0.71 \\
\hline $\mathrm{P}$ & 1.46 & 1.4 & - & - \\
\hline S & 0.62 & 0.67 & 0.53 & 0.25 \\
\hline $\mathrm{Cl}$ & 1.04 & 1.43 & 0.57 & 0.19 \\
\hline K & 0.63 & 0.68 & - & - \\
\hline $\mathrm{Ca}$ & 3.41 & 2.71 & - & - \\
\hline $\mathrm{Ni}$ & 3.39 & - & - & - \\
\hline $\mathrm{Fe}$ & - & - & - & 37.85 \\
\hline
\end{tabular}




\begin{tabular}{ccccc}
\hline Total & 100 & 100 & 100 & 100 \\
& & & \\
\hline
\end{tabular}
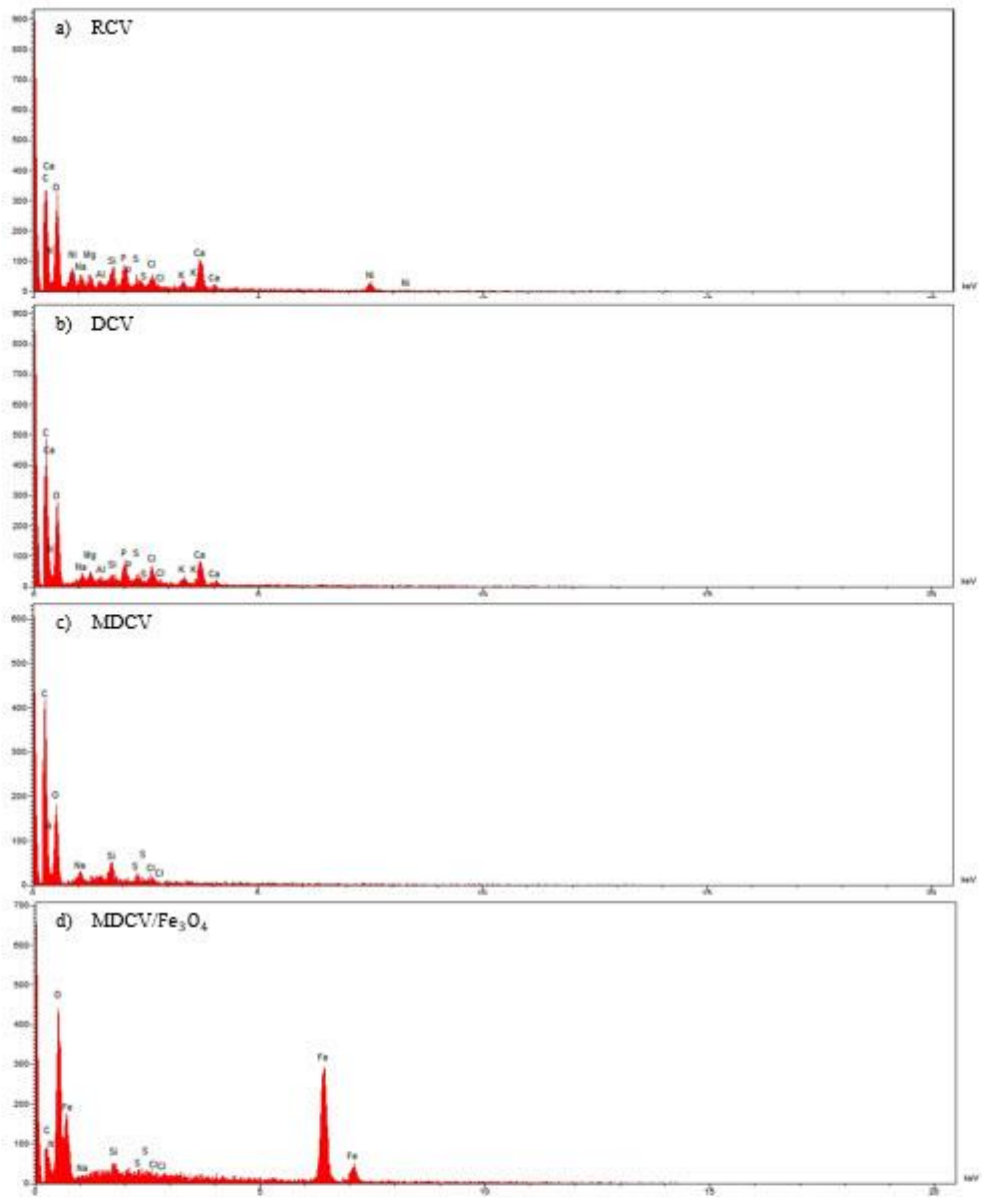

Figure (4) - EDS analysis for a) RCV, b) DCV, c) MDCV, and d) $\mathrm{MDCV} / \mathrm{Fe}_{3} \mathrm{O}_{4}$ 


\section{Brunauer-Emmett-Teller (BET)}

The BET analysis was performed for RCV, DCV, MDCV, and MDCV/Fe $\mathrm{O}_{3}$. Features such as specific surface area, average pore size, and porosity volume of samples were investigated in Table 6. The specific surface area of DCV and MDCV increased about 2 and 15 times, respectively, compared to RCV. The decrement in specific surface area of $\mathrm{MDCV} / \mathrm{Fe}_{3} \mathrm{O}_{4}$ compared to its nonmagnetic type was due to the coverage of some of its pores with iron particles. Nevertheless, the specific surface area of $\mathrm{MDCV} / \mathrm{Fe}_{3} \mathrm{O}_{4}$ compared to RCV has increased about 11 times. Thus, the appropriate modification process is confirmed on Chlorella vulgaris algae to prepare an easily separable biosorbent while increasing its specific surface area [43]. Fig. 5 shows the nitrogen adsorption-desorption isotherm for the samples. According to the classification of the International Union of Pure and Applied Chemistry (IUPAC), adsorption isotherms are defined in four groups called H1, H2, H3, and H4. The adsorption isotherms of RCV, DCV and MDCV are in H3, and $\mathrm{MDCV} / \mathrm{Fe}_{3} \mathrm{O}_{4}$ is in the $\mathrm{H} 1$ category. $\mathrm{H} 1$ represents materials with a porous structure that have spherical or cylindrical porous channels. $\mathrm{H} 3$ also represents materials with a soft and plate-like structure and porous slits $[44,45]$.

Based on the Barrett-Joyner-Halenda (BJH) diagram in Fig. 6, the structure of all samples contains micropores, mesopores, and macropores. While the largest distribution of the size of the pores belongs to the group of mesopores with a radius in the range of 2-25 $\mathrm{nm}$ [46].

Table (6) - BET analysis results of a) RCV, b) DCV, c) MDCV, and d) $\mathrm{MDCV} / \mathrm{Fe}_{3} \mathrm{O}_{4}$

\begin{tabular}{cccccc}
\hline Sample & \multicolumn{2}{c}{ Specific surface area $\left(\mathrm{m}^{2} / \mathrm{g}\right)$} & $\begin{array}{c}\text { Average pore size } \\
(\mathrm{nm})\end{array}$ & $\begin{array}{c}\text { Porosity volume } \\
\left(\mathrm{cm}^{3} / \mathrm{g}\right)\end{array}$ \\
\cline { 2 - 4 } & $\mathrm{BET}$ & $\mathrm{BJH}$ & Langmuir & & 0.013 \\
$\mathrm{RCV}$ & 2.30 & 2.91 & 2.08 & 23.84 & 0.021 \\
$\mathrm{DCV}$ & 5.27 & 7.73 & 3.45 & 16.21 & 0.119 \\
$\mathrm{MDCV}$ & 34.95 & 36.2 & 43.89 & 4.38 & 0.087 \\
$\mathrm{MDCV} / \mathrm{Fe}_{3} \mathrm{O}_{4}$ & 25.20 & 34.12 & 26.93 & 13.88 & \\
\hline
\end{tabular}



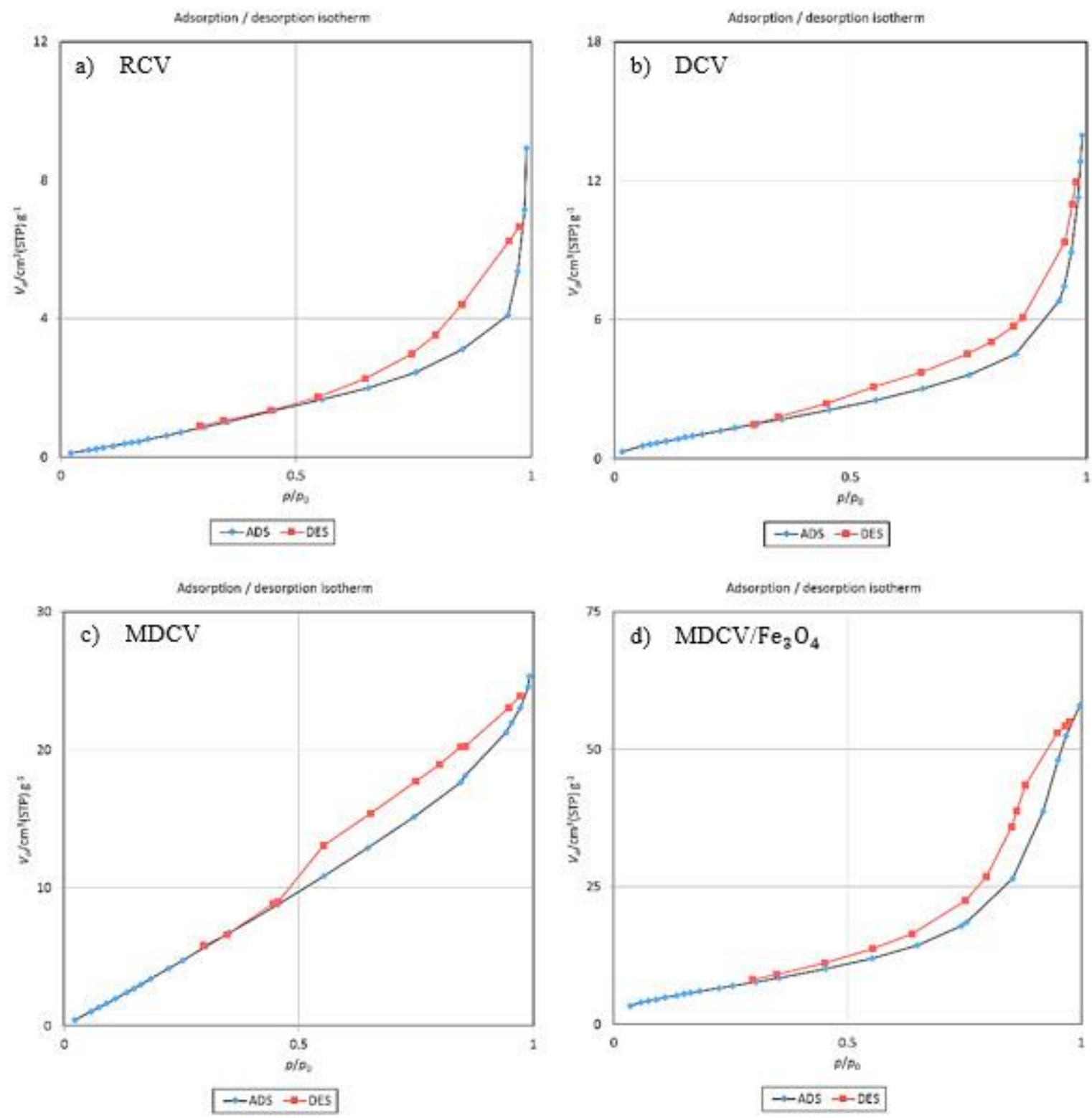

Figure (5) -Nitrogen adsorption-desorption isotherm for a) RCV, b) DCV, c) MDCV, and d) $\mathrm{MDCV} / \mathrm{Fe}_{3} \mathrm{O}_{4}$ 

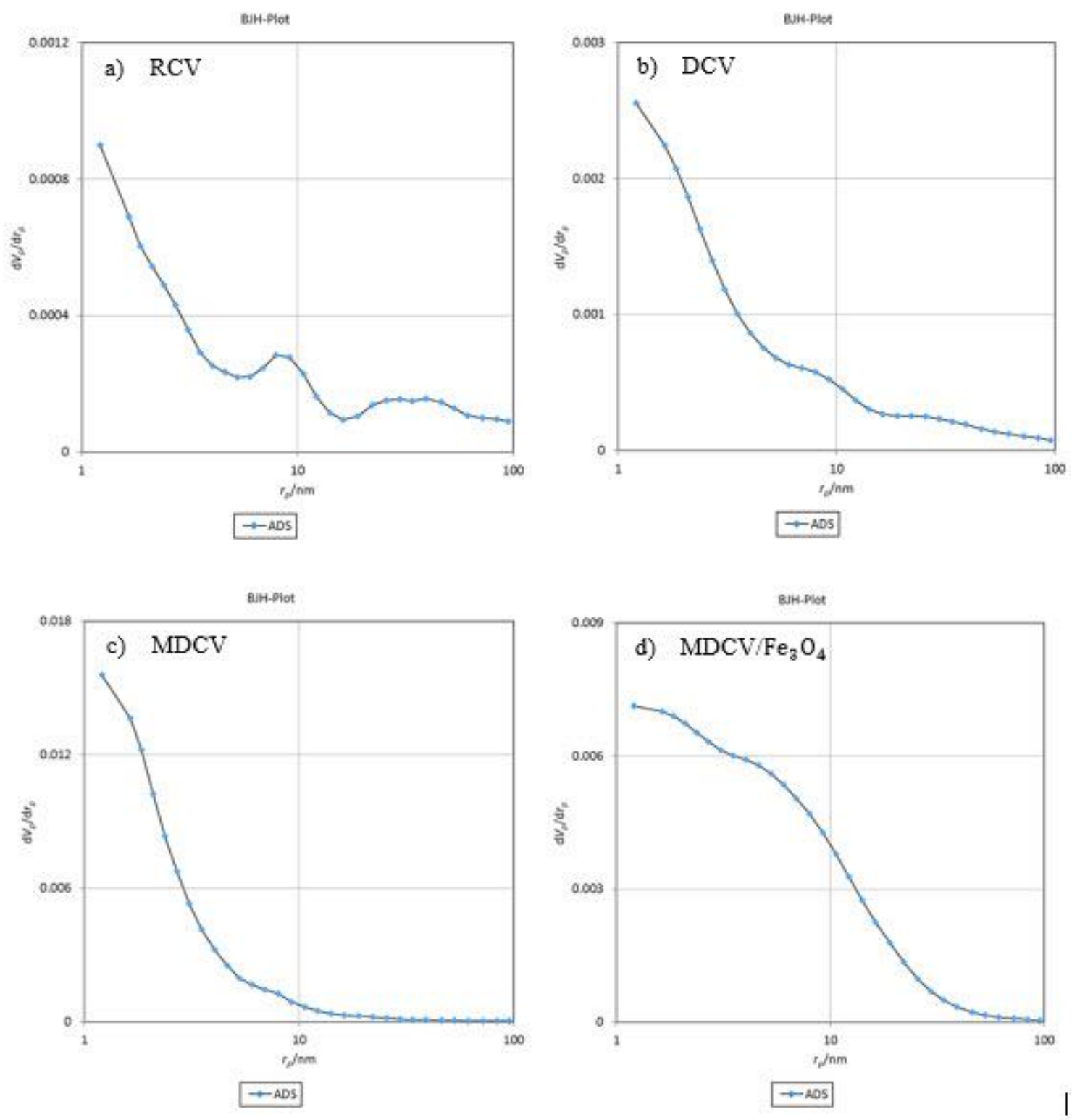

Figure (6) - BJH pore size distribution for a) RCV, b) DCV, c) MDCV, and d) $\mathrm{MDCV} / \mathrm{Fe}_{3} \mathrm{O}_{4}$

\section{Vibrating Sample Magnetometer (VSM)}

Based on Fig. 7, the magnetization hysteresis loops of $\mathrm{Fe}_{3} \mathrm{O}_{4}$ and $\mathrm{MDCV} / \mathrm{Fe}_{3} \mathrm{O}_{4}$ appeared S-like with no remanent magnetization and coercivity. It indicated the strong magnetic response to the different magnetic fields in paramagnetic materials. Therefore, they were easily separable by an external magnetic field and did not stick together when the magnetic field was removed [47]. The saturation magnetization of $\mathrm{Fe}_{3} \mathrm{O}_{4}$ and $\mathrm{MDCV} / \mathrm{Fe}_{3} \mathrm{O}_{4}$ were $78.64 \mathrm{emu} / \mathrm{g}$ and $38.89 \mathrm{emu} / \mathrm{g}$, respectively, which were suitable compared to the magnetic adsorbent derived from Chlorella 
vulgaris reported by $\mathrm{M}$. Govarthanan [48]. The decrease in $\mathrm{MDCV} / \mathrm{Fe}_{3} \mathrm{O}_{4}$ magnetization relative to $\mathrm{Fe}_{3} \mathrm{O}_{4}$ was due to changes in particle size, irregular bonding of particles, and surface spin disorientation $[49,50]$.

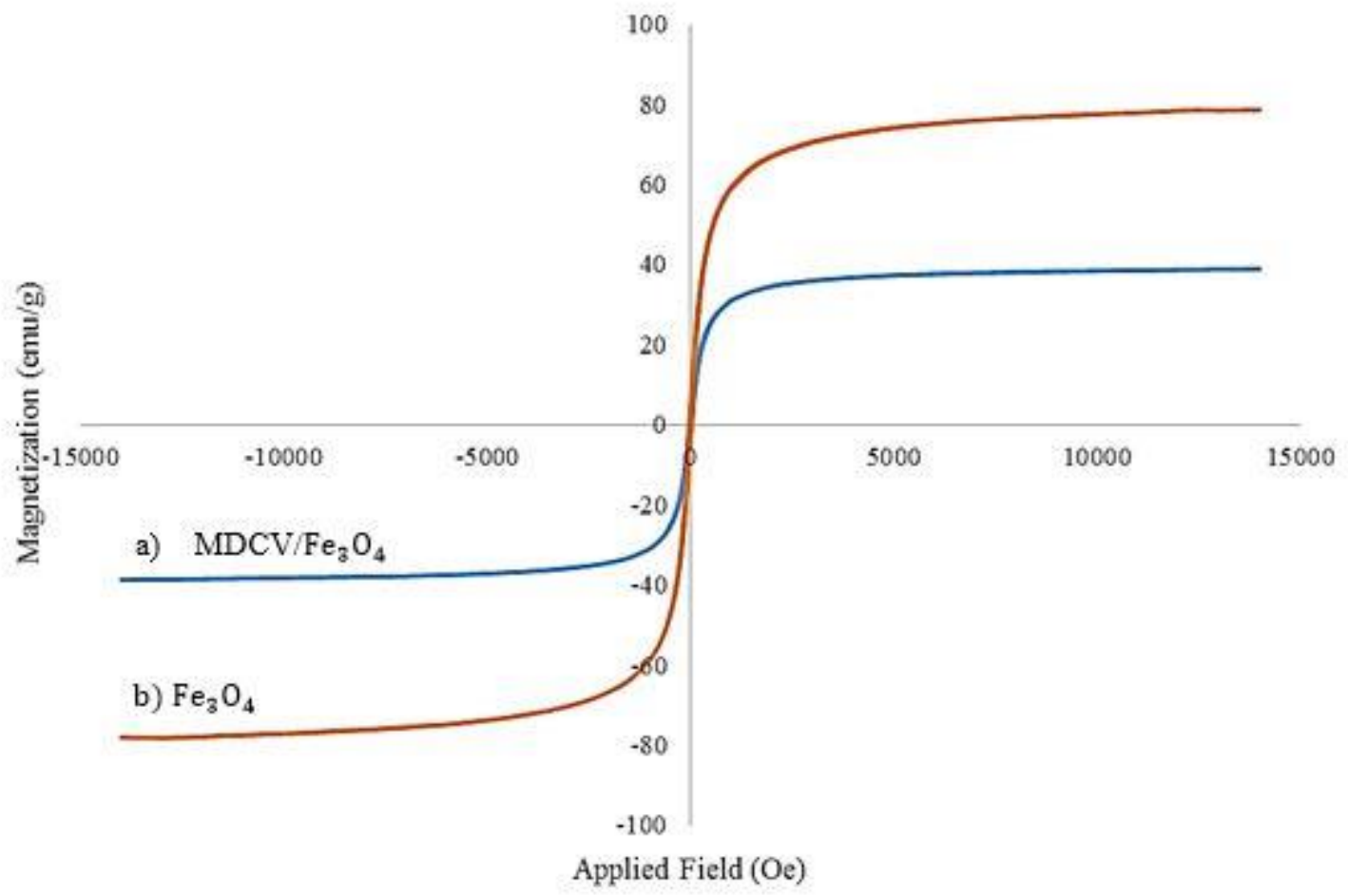

Figure (7) - VSM analysis for a) $\mathrm{MDCV} / \mathrm{Fe}_{3} \mathrm{O}_{4}$, b) $\mathrm{Fe}_{3} \mathrm{O}_{4}$

\section{Biosorption analysis}

Experimental results for biosorption analysis are reported in Table 7. Based on Equation 3, the multiple regression analysis of experimental data with $95 \%$ probability was used to study the effect of each parameter on the biosorption capacity of $\mathrm{MDCV} / \mathrm{Fe}_{3} \mathrm{O}_{4}$, kinetics, isotherms, and thermodynamic models. Ineffective variables were removed to increase the suitability of the models with experimental data. 
Table (7) - Experimental results of biosorption analysis from CCD proposed levels

\begin{tabular}{|c|c|c|c|c|c|c|}
\hline Run no. & $\mathrm{X}_{1}, \mathrm{~T}$ & $\mathrm{X}_{2}, \mathrm{t}$ & $\mathrm{X}_{3}, \mathrm{~m}$ & $\mathrm{X}_{4}, \mathrm{C}_{0}$ & $\mathrm{X}_{5}, \mathrm{pH}$ & $\mathrm{Y}, \mathrm{q}_{\mathrm{MDCV} / \mathrm{Fe}_{3} \mathrm{O}_{4}}$ \\
\hline 1 & -1 & -1 & -1 & -1 & 1 & 10.7565 \\
\hline 2 & 1 & -1 & -1 & -1 & -1 & 7.8790 \\
\hline 3 & -1 & 1 & -1 & -1 & -1 & 8.7164 \\
\hline 4 & 1 & 1 & -1 & -1 & 1 & 8.8619 \\
\hline 5 & -1 & -1 & 1 & -1 & -1 & 3.8118 \\
\hline 6 & 1 & -1 & 1 & -1 & 1 & 3.6523 \\
\hline 7 & -1 & 1 & 1 & -1 & 1 & 4.0791 \\
\hline 8 & 1 & 1 & 1 & -1 & -1 & 3.4669 \\
\hline 9 & -1 & -1 & -1 & 1 & -1 & 23.1100 \\
\hline 10 & 1 & -1 & -1 & 1 & 1 & 27.4232 \\
\hline 11 & -1 & 1 & -1 & 1 & 1 & 26.2010 \\
\hline 12 & 1 & 1 & -1 & 1 & -1 & 25.9489 \\
\hline 13 & -1 & -1 & 1 & 1 & 1 & 13.4475 \\
\hline 14 & 1 & -1 & 1 & 1 & -1 & 12.5616 \\
\hline 15 & -1 & 1 & 1 & 1 & -1 & 11.5723 \\
\hline 16 & 1 & 1 & 1 & 1 & 1 & 13.3958 \\
\hline 17 & -1 & 0 & 0 & 0 & 0 & 11.3094 \\
\hline 18 & 1 & 0 & 0 & 0 & 0 & 9.3598 \\
\hline 19 & 0 & -1 & 0 & 0 & 0 & 12.7255 \\
\hline 20 & 0 & 1 & 0 & 0 & 0 & 12.3278 \\
\hline
\end{tabular}




\begin{tabular}{ccccccc}
\hline 21 & 0 & 0 & -1 & 0 & 0 & 13.2300 \\
22 & 0 & 0 & 1 & 0 & 0 & 6.0006 \\
23 & 0 & 0 & 0 & -1 & 0 & 6.1024 \\
24 & 0 & 0 & 0 & 1 & 0 & 18.6266 \\
25 & 0 & 0 & 0 & 0 & -1 & 8.5650 \\
26 & 0 & 0 & 0 & 0 & 1 & 9.3695 \\
27 & 0 & 0 & 0 & 0 & 0 & 11.5809 \\
28 & 0 & 0 & 0 & 0 & 0 & 11.5809 \\
29 & 0 & 0 & 0 & 0 & 0 & 10.2133 \\
\hline
\end{tabular}

$Y=-3.72-0.0411 X_{1}-0.2702 X_{2}-0.1062 X_{3}+0.0994 X_{4}+5.72 X_{5}+0.002240 X_{2}^{2}+$ $0.001158 X_{4}^{2}-0.386 X_{5}^{2}+0.000664 X_{1} X_{4}-0.003177 X_{3} X_{4}$

The compatibility of the models with data is proven by the ANOVA results of recent regression. Based on Table 8, the calculated Fisher distributions is greater than its critical value. Also, the Pvalue is less than 0.000 . The adjusted determination coefficient of model $\mathrm{Y}$ is $98.35 \%$ [51].

Table (8) - ANOVA of the quadratic models of the $\mathrm{MDCV} / \mathrm{Fe}_{3} \mathrm{O}_{4}$ biosorption capacity

\begin{tabular}{ccccccccc}
\hline Response & $\begin{array}{c}\text { Variation } \\
\text { source }\end{array}$ & $\mathrm{df}$ & $\mathrm{SS}$ & $\mathrm{MSS}$ & $\mathrm{F}_{\text {calc. }}$ & $\mathrm{F}_{\mathrm{c}}$ & P-value & $\mathrm{R}_{\text {adj }}^{2}$ \\
& Regression & 10 & 1207.00 & 120.70 & 168.20 & 2.19 & 0.00 & $98.35 \%$ \\
\hline $\begin{array}{c}\mathrm{MDCV} / \mathrm{Fe}_{3} \mathrm{O}_{4} \\
\text { biosorption capacity, }\end{array}$ & Error & 18 & 12.92 & 0.718 & - & - & - & - \\
$\mathrm{Y}$ & Total & 28 & 1219.92 & - & - & - & - & - \\
& & & & & & & & \\
\hline
\end{tabular}

According to Table 9, the P-values of all coefficients of the effective variables in $\mathrm{Y}$ analysis are less than 0.05. Since the coefficients of interactions of $X_{2}^{2}$ and $X_{1} X_{4}$ are significant, $X_{1}$ and $X_{2}$ can not be ignored [51]. 
Table (9) - Estimated regression coefficients for the quadratic model of the $\mathrm{MDCV} / \mathrm{Fe}_{3} \mathrm{O}_{4}$ biosorption capacity

\begin{tabular}{ccccc}
\hline Terms & Uncoded coefficient & $\begin{array}{c}\text { The standard error of the } \\
\text { coefficient }\end{array}$ & t-value & P-value \\
\hline constant & -3.72 & 0.274 & 38.26 & 0.000 \\
$\mathrm{X}_{1}$ & -0.0411 & 0.200 & -0.13 & 0.901 \\
$\mathrm{X}_{2}$ & -0.2702 & 0.200 & -0.22 & 0.827 \\
$\mathrm{X}_{3}$ & -0.1062 & 0.200 & -22.30 & 0.000 \\
$\mathrm{X}_{4}$ & 0.0994 & 0.200 & 31.99 & 0.000 \\
$\mathrm{X}_{5}$ & 5.72 & 0.200 & 3.22 & 0.005 \\
$\mathrm{X}_{2}^{2}$ & 0.002240 & 0.504 & 4.00 & 0.001 \\
$\mathrm{X}_{4}^{2}$ & 0.001158 & 0.504 & 3.68 & 0.002 \\
$\mathrm{X}_{5}^{2}$ & -0.386 & 0.504 & -3.06 & 0.007 \\
$\mathrm{X}_{1} \mathrm{X}_{4}$ & 0.000664 & 0.212 & 2.51 & 0.022 \\
$\mathrm{X}_{3} \mathrm{X}_{4}$ & -0.003177 & 0.212 & -9.00 & 0.000 \\
\hline
\end{tabular}

\section{Effect of contact time}

The biosorption capacity of $\mathrm{MDCV} / \mathrm{Fe}_{3} \mathrm{O}_{4}$ was plotted in Fig. 8a. The biosorption capacity is zero at the beginning of the process. It reaches the maximum levels during the first five minutes. Then, it decreases over time and reaches equilibrium mode. This phenomenon is called repulsion. It occurs when large biosorption surface areas are available and rapidly covered by MB molecules in the first few minutes [52-54]. Eventually, the system reaches equilibrium after a while of biosorption and desorption. In the first minutes, the higher MB concentration, due to the high driving forces of mass transfer, increase the biosorption capacity. So the highest MB removal efficiency appears in the first minutes before the time of equilibrium. After reaching equilibrium, the removal efficiency of $\mathrm{MB}$ by $\mathrm{MDCV} / \mathrm{Fe}_{3} \mathrm{O}_{4}$ at initial concentrations of 20,60 , and $100 \mathrm{mg} / \mathrm{L}$ are about $63 \%, 37 \%$ and $37 \%$, respectively. 


\section{Effect of $\mathbf{p H}$}

The $\mathrm{pH}$ of the solution significantly affects the relationship between biosorbent and adsorbate. On the other hand, the interactions of hydrogen ions, Van der Waals forces, and the propagation of cavities, also affect the biosorption rate. As can be seen in Fig. 8b, the amounts of biosorption capacity in $\mathrm{pH} 3$ to 7 increased from 17.6 to $25 \mathrm{mg} / \mathrm{g}$ and then it decreased to $13 \mathrm{mg} / \mathrm{g}$ as the $\mathrm{pH}$ increased to 9. The cell wall of Chlorella vulgaris contains a large number of functional groups, carboxylic acid. Therefore, at low $\mathrm{pH}$, cell wall ligands are protonated and the $\mathrm{H}^{+}$also increases. As a result, the biosorption capacity decreased due to the competition between $\mathrm{H}^{+}$and cationic molecules of $\mathrm{MB}$. As the $\mathrm{pH}$ increased and $\mathrm{OH}^{-}$formed, more ligands, such as the amino and carboxyl functional groups, were exposed to the attraction between $\mathrm{OH}^{-}$and $\mathrm{MB}$ cationic molecules. The competition between $\mathrm{H}^{+}$and $\mathrm{MB}$ also decreased, so the biosorption capacity of $\mathrm{MDCV} / \mathrm{Fe}_{3} \mathrm{O}_{4}$ increased $[55,56]$. At higher $\mathrm{pHs}$, the presence of ions, MB cationic molecules, and the interactions of charges increased the forces between MB monomer molecules. This phenomenon had led to the formation of MB dimer molecules, which were probably larger than the size of surface holes. This difference in sizes reduced the number of active surface cavities and caused less biosorption capacity [57].

\section{Effect of biosorbent dosage}

Based on Fig. 8c, the development of biosorbent amount increases the removal efficiency of MB due to the increment of active sites for dye biosorption. While the reduction in biosorption capacity by increasing the amount of biosorbent is due to the gradient of the biosorbent and adsorbate concentration. The factors influencing biosorption are investigated based on the biosorbent mass unit. As a result, phenomena such as aggregation and condensation cause many active levels to remain unused, thereby reducing biosorption capacity. It is observed that the biosorption capacity and removal efficiency of $\mathrm{MB}$ in the biosorbent amounts of 15 to $45 \mathrm{mg}$ has changed from $25 \mathrm{mg} / \mathrm{g}$ and $37 \%$ to $12 \mathrm{mg} / \mathrm{g}$ and $55 \%$, respectively $[58,59]$.

\section{Effect of the initial concentration of $\mathrm{MB}$}

Changes in the biosorption capacity and removal efficiency of MB are calculated according to the changes in the initial concentration of $\mathrm{MB}$ and reported in Fig. 8d. By changing the initial concentration of $\mathrm{MB}$ from 20 to $100 \mathrm{mg} / \mathrm{L}$, the biosorption capacity has increased from 8.5 to 25 
$\mathrm{mg} / \mathrm{g}$, due to mass transfer-driving forces. As mentioned in the previous section, the removal efficiency of MB is directly related to the number of active sites of the biosorbent. Therefore, at a constant biosorbent dosage, with increasing the initial concentration of $\mathrm{MB}$, the active sites of the biosorbent decrease and lead to the reduction in removal efficiency from $63 \%$ to $37 \%$ [60].

\section{Effect of temperature}

As mentioned in the ANOVA analysis section, the temperature does not significantly affect the $\mathrm{MDCV} / \mathrm{Fe}_{3} \mathrm{O}_{4}$ biosorption capacity. According to Fig. 8e, with increasing temperature from 5 to $45^{\circ} \mathrm{C}$, the biosorption capacity of $\mathrm{MDCV} / \mathrm{Fe}_{3} \mathrm{O}_{4}$ with initial $\mathrm{MB}$ concentration of $60 \mathrm{mg} / \mathrm{L}$ did not change much and with initial MB concentrations of $20 \mathrm{mg} / \mathrm{L}$ and $100 \mathrm{mg} / \mathrm{L}$ was associated with a decrease of $12 \%$ and an increase of $4 \%$, respectively. Similar results were observed in recent research by Konig-Peter Aniko et al. [61]. These differences in the behavior of $\mathrm{MDCV} / \mathrm{Fe}_{3} \mathrm{O}_{4}$ biosorption capacity relative to temperature indicates that the biosorption process is entropically rather than enthalpically driven [62]. 

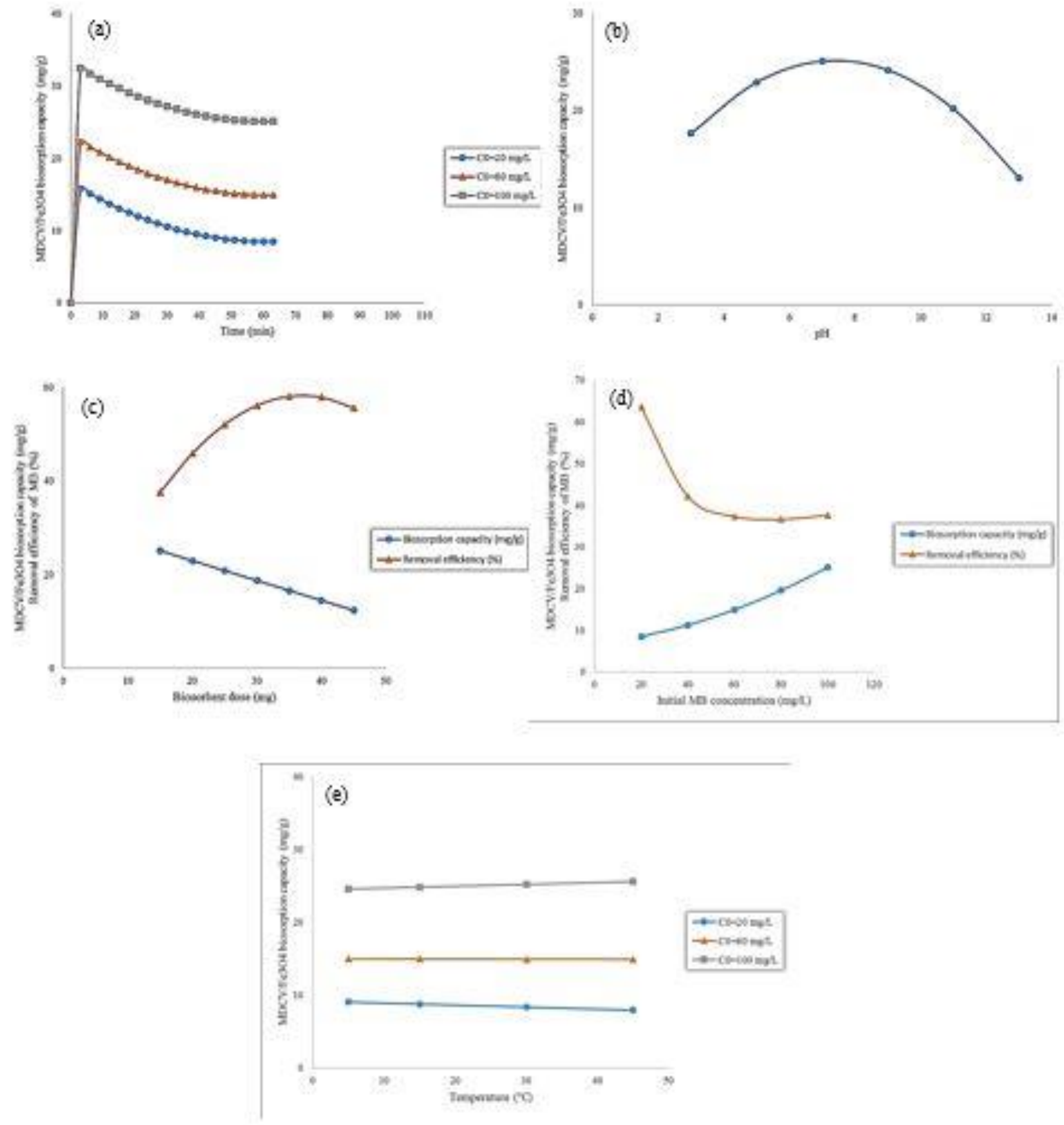

Figure (8) - Effect of a) contact time $\left.\left(\mathrm{T}=25^{\circ} \mathrm{C}, \mathrm{m}=15 \mathrm{mg}, \mathrm{pH}=7\right), \mathrm{b}\right) \mathrm{pH}\left(\mathrm{T}=25^{\circ} \mathrm{C}, \mathrm{t}=60 \mathrm{~min}, \mathrm{~m}=15 \mathrm{mg}, \mathrm{C} 0=100\right.$ $\mathrm{mg} / \mathrm{L}), \mathrm{c})$ biosorbent dosage $\left.\left(\mathrm{T}=25^{\circ} \mathrm{C}, \mathrm{t}=60 \mathrm{~min}, \mathrm{C} 0=100 \mathrm{mg} / \mathrm{L}, \mathrm{pH}=7\right), \mathrm{d}\right)$ initial concentration of $\mathrm{MB}\left(\mathrm{T}=25^{\circ} \mathrm{C}\right.$, $\mathrm{t}=60 \mathrm{~min}, \mathrm{~m}=15 \mathrm{mg}, \mathrm{pH}=7)$, and e) temperature ( $\mathrm{t}=60 \mathrm{~min}, \mathrm{~m}=15 \mathrm{mg}, \mathrm{pH}=7)$ on biosorption of $\mathrm{MB}$ by $\mathrm{MDCV} / \mathrm{Fe}_{3} \mathrm{O}_{4}$ 


\section{Biosorption kinetics}

Kinetic trends and their parameters are reported in Fig. 9 and Table 10. Due to the downward trend in biosorption capacity over time, the pseudo-first-order model cannot be examined [63]. The determination coefficients of the pseudo-second-order model in all initial concentrations of MB are greater than 0.99 . Also, the equilibrium biosorption capacities calculated in this model are very close to the experimental amounts. Therefore, this model is a good predictor of the kinetics of MB biosorption on the $\mathrm{MDCV} / \mathrm{Fe}_{3} \mathrm{O}_{4}$ and more compatible than the intraparticle diffusion model [63]. Based on the intraparticle diffusion model, increasing the value of surface biosorption (intercept, C) with increasing temperature indicates a decrease in the rate of diffusion of MB from the external surface to the internal surfaces of biosorbent [64].
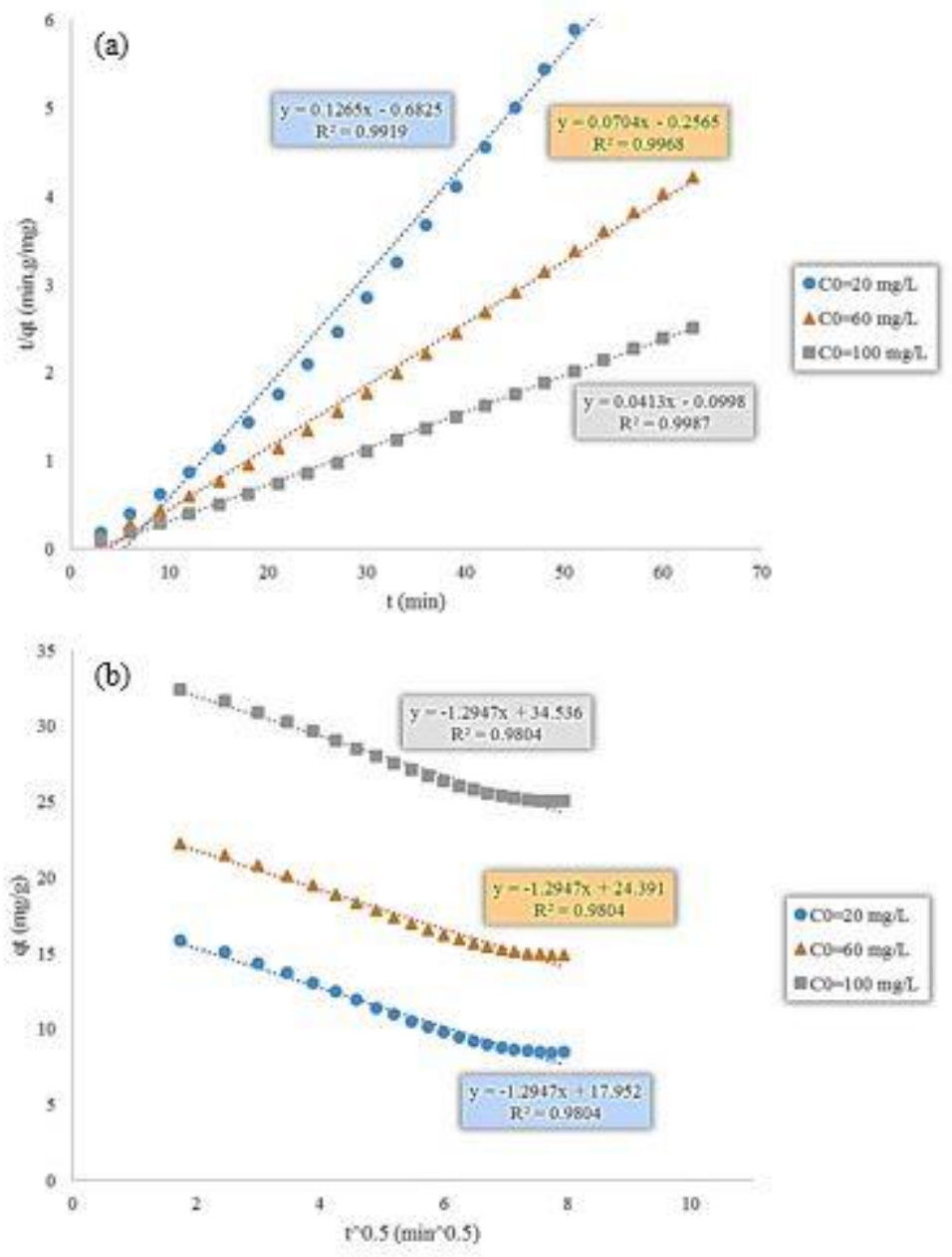

Figure (9) - Plots of a) pseudo-second-order, b) intraparticle diffusion kinetic models for MB biosorption onto $\mathrm{MDCV} / \mathrm{Fe}_{3} \mathrm{O}_{4}\left(\mathrm{~T}=25^{\circ} \mathrm{C}, \mathrm{m}=15 \mathrm{mg}, \mathrm{pH}=7\right)$ 
Table (10) - Kinetic parameters for MB biosorption onto $\mathrm{MDCV} / \mathrm{Fe}_{3} \mathrm{O}_{4}$

\begin{tabular}{|c|c|c|c|}
\hline \multirow[t]{2}{*}{ Parameter } & \multicolumn{3}{|c|}{ Concentration (mg/L) } \\
\hline & 20 & 60 & 100 \\
\hline $\mathrm{q}_{\mathrm{e}, \exp }\left(\mathrm{mg} \cdot \mathrm{g}^{-1}\right)$ & 8.46 & 14.90 & 25.05 \\
\hline $\mathrm{t}_{\mathrm{e}}(\min )$ & 60 & 60 & 60 \\
\hline \multicolumn{4}{|l|}{ Pseudo-second-order } \\
\hline $\mathrm{q}_{\mathrm{e}, \mathrm{cal}}\left(\mathrm{mg} \cdot \mathrm{g}^{-1}\right)$ & 7.90 & 14.20 & 24.21 \\
\hline $\mathrm{k}_{2}\left(\mathrm{~g} \cdot \mathrm{mg}^{-1} \cdot \mathrm{min}^{-1}\right)$ & -0.0234 & -0.0193 & -0.0170 \\
\hline $\mathrm{R}^{2}$ & 0.99 & 0.99 & 0.99 \\
\hline \multicolumn{4}{|l|}{ Intraparticle diffusion } \\
\hline $\mathrm{k}_{\mathrm{id}}\left(\mathrm{mg} \cdot \mathrm{g}^{-1} \cdot \min ^{0.5}\right)$ & -1.2947 & -1.2947 & -1.2947 \\
\hline $\mathrm{C}\left(\mathrm{mg} \cdot \mathrm{g}^{-1}\right)$ & 17.952 & 24.391 & 34.536 \\
\hline $\mathrm{R}^{2}$ & 0.98 & 0.98 & 0.98 \\
\hline
\end{tabular}

\section{Biosorption isotherms}

Comparing the results of Fig. 10 and Table 11, Freundlich isotherm has the highest compatibility with data compared to Langmuir and Temkin. The equilibrium parameters of the Langmuir isotherm $\left(\mathrm{R}_{\mathrm{L}}\right)$ are in the range of $0<\mathrm{R}_{\mathrm{L}}<1$. Also, in the Freundlich isotherm, the values of $1 / \mathrm{n}$ are in the range of $0<1 / \mathrm{n}<1$. So, the biosorption of $\mathrm{MB}$ onto $\mathrm{MDCV} / \mathrm{Fe}_{3} \mathrm{O}_{4}$ is desirable [65, 66]. The values of $\mathrm{K}_{\mathrm{f}}$ also indicate a growth in biosorption capacity with decreasing temperature. The decreasing of $b_{t}$ with increasing temperature in Temkin isotherm, indicates an exothermic biosorption [67]. 

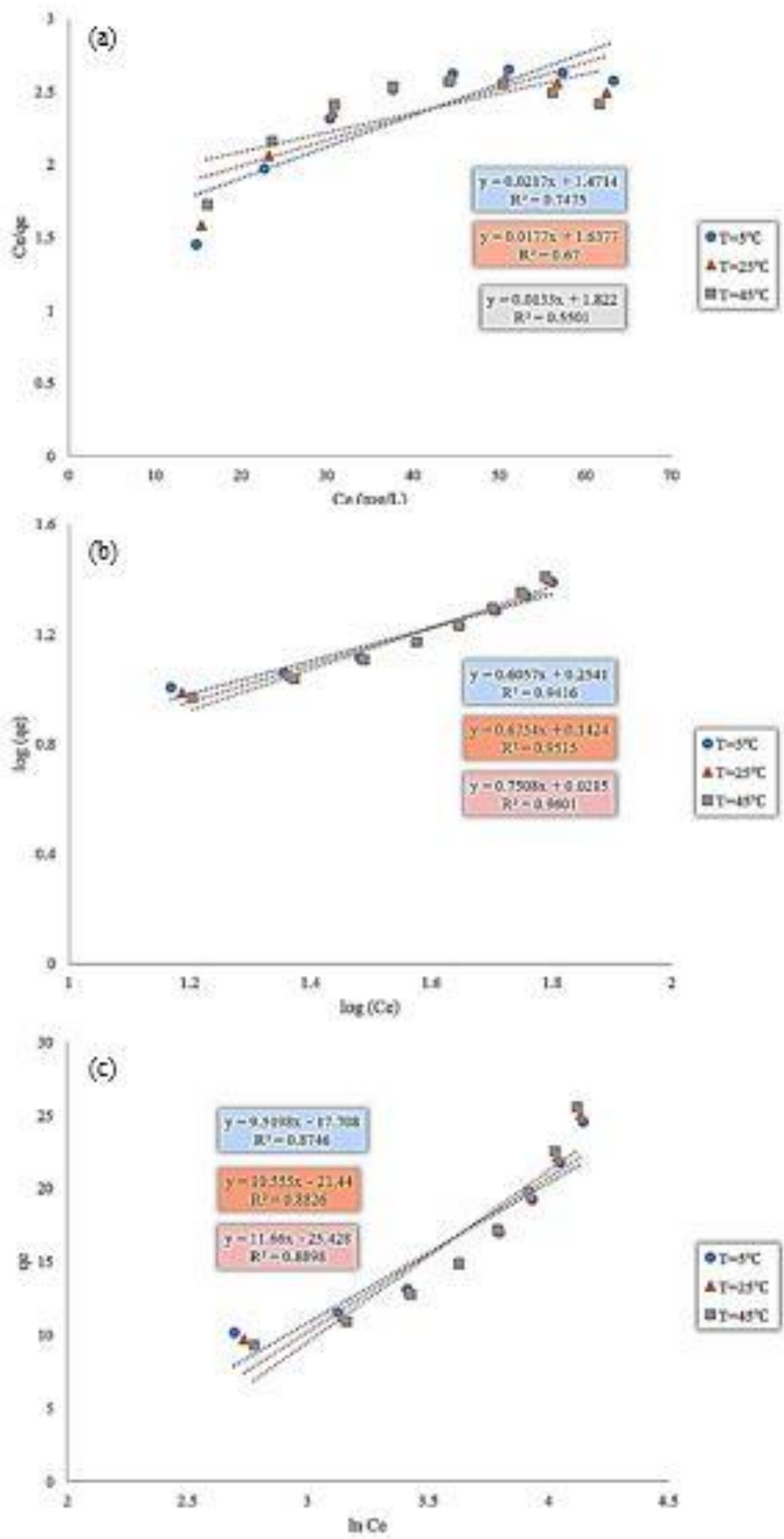

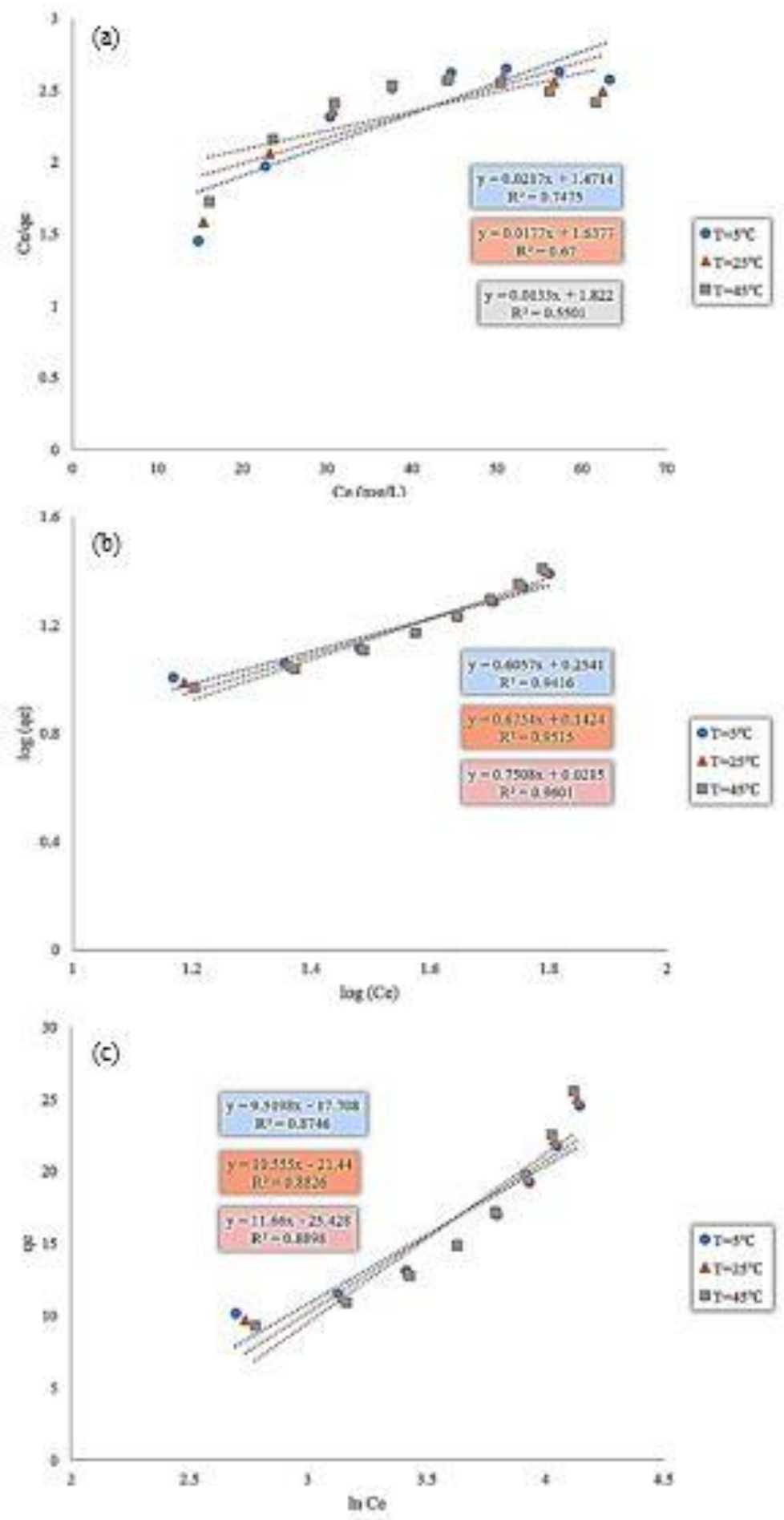

Figure (10) - Plots of a) Langmuir, b) Freundlich, c) Temkin isotherm models for MB biosorption onto $\mathrm{MDCV} / \mathrm{Fe}_{3} \mathrm{O}_{4}$ 
Table (11) - Isotherm parameters for $\mathrm{MB}$ biosorption onto $\mathrm{MDCV} / \mathrm{Fe}_{3} \mathrm{O}_{4}$

\begin{tabular}{|c|c|c|c|}
\hline \multirow[t]{2}{*}{ Parameter } & \multicolumn{3}{|c|}{ Temperature $\left({ }^{\circ} \mathrm{C}\right)$} \\
\hline & 5 & 25 & 45 \\
\hline \multicolumn{4}{|l|}{ Langmuir } \\
\hline $\mathrm{K}_{\mathrm{L}}\left(\mathrm{L} \cdot \mathrm{mg}^{-1}\right)$ & 0.014 & 0.010 & 0.007 \\
\hline $\mathrm{q}_{\mathrm{m}}\left(\mathrm{mg} \cdot \mathrm{g}^{-1}\right)$ & 46.08 & 56.50 & 75.18 \\
\hline $\mathrm{R}_{\mathrm{L}}$ & $0.40-0.69$ & $0.48-0.75$ & $0.58-0.82$ \\
\hline $\mathrm{R}^{2}$ & 0.74 & 0.67 & 0.55 \\
\hline \multicolumn{4}{|l|}{ Freundlich } \\
\hline $\mathrm{K}_{\mathrm{F}}\left(\left(\mathrm{mg} \cdot \mathrm{g}^{-1}\right)\left(\mathrm{mg} \cdot \mathrm{L}^{-1}\right)^{1 / \mathrm{n}}\right)$ & 1.79 & 1.38 & 1.05 \\
\hline $\mathrm{n}$ & 1.65 & 1.48 & 1.33 \\
\hline $\mathrm{R}^{2}$ & 0.94 & 0.95 & 0.96 \\
\hline \multicolumn{4}{|l|}{ Temkin } \\
\hline $\mathrm{b}_{\mathrm{t}}\left(\mathrm{J} \cdot \mathrm{g} \cdot \mathrm{mol}^{-1} \cdot \mathrm{mg}^{-1}\right)$ & 242.78 & 234.72 & 226.74 \\
\hline $\mathrm{K}_{\mathrm{T}}\left(\mathrm{L} \cdot \mathrm{mg}^{-1}\right)$ & 0.15 & 0.13 & 0.11 \\
\hline $\mathrm{R}^{2}$ & 0.87 & 0.88 & 0.88 \\
\hline
\end{tabular}

\section{Biosorption thermodynamic}

The Van't Hoff plot of $\ln K_{c}$ versus $1 / T$ is shown in Fig. 11. The calculated thermodynamic parameters are reported in Table 12. Positive values of $\Delta G$ indicate the non-spontaneous biosorption of $\mathrm{MB}$ onto $\mathrm{MDCV} / \mathrm{Fe}_{3} \mathrm{O}_{4}$, which grows with increasing temperature [50]. The result of changes in the energy of the biosorption and desorption has led to a negative amount of $\Delta H$. As a result, the biosorption process of $\mathrm{MB}$ on $\mathrm{MDCV} / \mathrm{Fe}_{3} \mathrm{O}_{4}$ is exothermic [68]. Based on previous studies and considering the enthalpy value $(-46.56 \mathrm{~kJ} / \mathrm{mol})$, the biosorption process of MB onto $\mathrm{MDCV} / \mathrm{Fe}_{3} \mathrm{O}_{4}$, is considered as almost physical biosorption [69,70]. The negative value of $\Delta S$ 
also indicates a reduction in randomness and irregularity of MB particles when they are placed on the active sites of biosorbent [71].

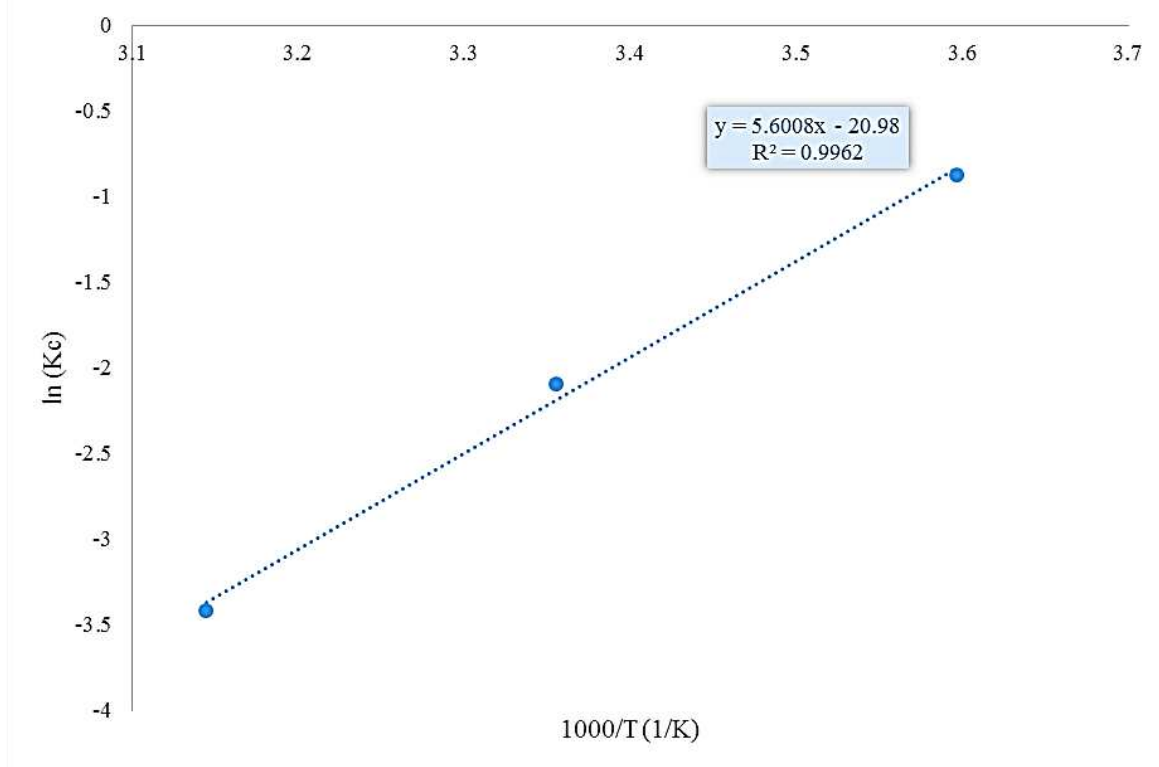

Figure (11) - Van't Hoff diagram for the estimation of thermodynamic parameters Table (12) - Thermodynamic parameters for MB biosorption onto MDCV/Fe $\mathrm{O}_{3}$

\begin{tabular}{|c|c|c|c|c|}
\hline \multirow[t]{2}{*}{ Parameter } & \multicolumn{3}{|c|}{ Temperature $(\mathrm{K})$} & \multirow[t]{2}{*}{$\mathrm{R}^{2}$} \\
\hline & 278 & 298 & 318 & \\
\hline $\mathrm{K}_{\mathrm{c}}$ & 0.4167 & 0.1230 & 0.0328 & 0.99 \\
\hline$\Delta \mathrm{H}\left(\mathrm{kJ} \cdot \mathrm{mol}^{-1}\right)$ & & -46.56 & & \\
\hline$\Delta \mathrm{S}\left(\mathrm{kJ} \cdot \mathrm{mol}^{-1} \cdot \mathrm{K}^{-1}\right)$ & & -0.17 & & \\
\hline$\Delta \mathrm{G}\left(\mathrm{kJ} \cdot \mathrm{mol}^{-1}\right)$ & 1.92 & 5.41 & 8.90 & \\
\hline
\end{tabular}

\section{Comparison of $\mathrm{MDCV} / \mathrm{Fe}_{3} \mathrm{O}_{4}$ with other biosorbents}

The maximum biosorption capacity of the biosorbents depends on the modification method and the type of dyes. The maximum biosorption capacity of $\mathrm{MDCV} / \mathrm{Fe}_{3} \mathrm{O}_{4}$ is $32.44 \mathrm{mg} / \mathrm{g}$ at temperature $\left(45^{\circ} \mathrm{C}\right)$, contact time $(5 \mathrm{~min})$, biosorbent dosage $(15 \mathrm{mg})$, initial concentration of $\mathrm{MB}(100 \mathrm{mg} / \mathrm{L})$, and $\mathrm{pH}$ (7). Comparison of $\mathrm{MDCV} / \mathrm{Fe}_{3} \mathrm{O}_{4}$ with other biosorbents for $\mathrm{MB}$ biosorption was 
performed in Table 13. The results show that the maximum biosorption capacity of MDCV/Fe $3 \mathrm{O}_{4}$ is good. Although this amount is lower than some biosorbents such as biochars and their activated carbons, it is promising and even higher compared to some green, red, and brown algae with similar modifications. On the other hand, few studies have been done on the modified dry Chlorella vulgaris. Therefore, this study offers a useful approach in MB biosorption with maximum removal efficiency during the shortest time.

Table (13) - Comparison of MDCV/Fe $e_{3} O_{4}$ maximum biosorption capacity $\left(q_{m}, m g / g\right)$ with other biosorbents

\begin{tabular}{|c|c|c|c|}
\hline Biosorbent & Modification & $\begin{array}{c}\text { Maximum biosorption } \\
\text { capacity }(\mathrm{mg} / \mathrm{g})\end{array}$ & Ref. \\
\hline Enteromorpha spp. & - & 274 & [72] \\
\hline Nizamuddinia zanardinii & - & 863.4 & [73] \\
\hline $\begin{array}{c}\text { Magnetic wakame biochar } \\
\text { nanocomposites }\end{array}$ & $\begin{array}{l}\text { Magnetization } \\
\text { Loading nickel on biochar }\end{array}$ & 479.49 & [74] \\
\hline $\begin{array}{l}\text { Ultrasonicated activated carbon of } \\
\text { empty fruit bunch }\end{array}$ & Ultrasonication & 435 & [71] \\
\hline Activated carbon of Empty Fruit Bunch & - & 400 & [71] \\
\hline Aegagropila Linnaei & - & 250 & {$[75]$} \\
\hline Chemical modified Aegagropila Linnaei & $\begin{array}{l}\text { Extracted functionalized } \\
\text { cellulose }\end{array}$ & 100 & {$[75]$} \\
\hline EDTA-modified bentonite & Modification with EDTA & 160 & {$[76]$} \\
\hline Gracilaria parvispora & - & 83.08 & {$[73]$} \\
\hline Palm leaflets & - & 72.3 & {$[77]$} \\
\hline Palm frond base & - & 70.87 & [77] \\
\hline Cystoseira barbatula & - & 38.61 & [78] \\
\hline Raw wet Chlorella vulgaris & - & 10.142 & [79] \\
\hline
\end{tabular}




\begin{tabular}{|c|c|c|c|}
\hline Annona squmosa seed & Sulfuric acid activation & 8.52 & [80] \\
\hline S. dimorphus & - & 6 & [81] \\
\hline \multicolumn{4}{|l|}{$(\mathrm{DAB})$} \\
\hline Sulfuric acid pretreated DAB & Sulfuric acid pretreatment & 7.80 & [81] \\
\hline Raw posidonia oceanica fibres & - & 5.56 & [82] \\
\hline Caulerpa racemosa var. cylindracea & - & 5.23 & [83] \\
\hline This work & Lipid extraction & 32.44 & - \\
\hline & $\begin{array}{l}\text { Phosphoric acid } \\
\text { modification }\end{array}$ & & \\
\hline & Magnetization & & \\
\hline
\end{tabular}

\section{Conclusion}

In this work, Chlorella vulgaris algae was examined to remove MB from wastewater. This study showed that lipid extraction could provide a good opportunity to use algae residues after the esterification process as an economic biosorbent. Optimization of the variables in the phosphoric acid modification process ensured the maximization of the biosorption capacity and residual defatted algae. Finally, the modified defatted algae were magnetized for easy and low-cost separation of the biosorbent. The specific surface area of the magnetic modified defatted algae $\left(\mathrm{MDCV} / \mathrm{Fe}_{3} \mathrm{O}_{4}\right.$ ) reached $25.2 \mathrm{~m}^{2} / \mathrm{g}$. So a novel magnetic biosorbent was considered to remove MB. Parameters affecting the biosorption were investigated to increase the biosorption capacity of $\mathrm{MDCV} / \mathrm{Fe}_{3} \mathrm{O}_{4}$. The pseudo-second-order kinetic model was well matched to the data. Equilibrium data were well described by the Freundlich model. MB biosorption on the selected biosorbent was non-spontaneous and exothermic. This process was associated with decreasing irregularity and randomness at the interface of dye and biosorbent. This study proved that Chlorella vulgaris can be used as a cheap and available source to remove the MB dye pollutant. 


\section{Methods}

\section{Materials}

Chlorella vulgaris algae were obtained from the Biotechnology Laboratory, Faculty of Chemical Engineering, University of Tehran, Tehran, Iran. Chloroform $\left(\mathrm{CHCl}_{3}, 98 \%\right)$, methanol $\left(\mathrm{CH}_{3} \mathrm{OH}, 99.5 \%\right)$, ortho-phosphoric acid $\left(\mathrm{H}_{3} \mathrm{PO}_{4}, 85 \%\right)$ and sodium carbonate anhydrous $\left(\mathrm{Na}_{2} \mathrm{CO}_{3}, 99.9 \%\right)$ were purchased for extraction of lipids and acid treatment from Merck. For magnetization, iron (II) sulfate heptahydrate $\left(\mathrm{FeSO}_{4} \cdot 7 \mathrm{H}_{2} \mathrm{O}, 99 \%\right)$, iron (III) chloride hexahydrate $\left(\mathrm{FeCl}_{3} \cdot 6 \mathrm{H}_{2} \mathrm{O}, 99 \%\right)$, and ammonia $\left(\mathrm{NH}_{4} \mathrm{OH}, 25 \mathrm{wt} \%\right)$ was purchased from Merck. Methylene blue Powder $\left(\mathrm{C}_{16} \mathrm{H}_{18} \mathrm{ClN}_{3} \mathrm{~S}, \geq 82 \%\right)$, sodium hydroxide $(\mathrm{NaOH}, 98 \%)$, and hydrochloric acid $(\mathrm{HCl}, 37 \%)$ were purchased from Merck for the biosorption process. All chemicals are in the analytical grade.

\section{Biosorbent preparation}

Raw Chlorella vulgaris algae (RCV) was first washed several times with distilled water to remove impurities and dried at $45^{\circ} \mathrm{C}$ for $24 \mathrm{hr}$. Then it was powdered with mortar.

\section{Lipid extraction}

Lipid extraction of RCV was performed by ultrasonic cell destruction and Soxhlet extraction setup [84]. First, $10 \mathrm{~g}$ of RCV was mixed with $10 \mathrm{~mL}$ of methanol. Then it was sonicated with the frequency of $28 \mathrm{kHz}$ at room temperature for 40 minutes. The sonicated RCV was then transferred to a cartridge and placed inside the Soxhlet setup. As a solvent mixture, $285 \mathrm{~mL}$ of chloroform:methanol (1:2 v/v) was poured into the flask according to Bligh \& Dyer method [85]. Extraction was carried out for $24 \mathrm{hr}$ at $65^{\circ} \mathrm{C}$. The defatted Chlorella vulgaris (DCV) was washed several times with distilled water to remove the remaining solvent and dried at $50^{\circ} \mathrm{C}$ for $24 \mathrm{hr}$. Dry DCV was powdered with a mortar and used for the next steps.

\section{Phosphoric acid treatment and optimization of parameters}

DCV was exposed to a dilute phosphoric acid solution under specified conditions. The central composite design (CCD) was used by the response surface methodology (RSM) to design experiments. Coded \& uncoded levels of variables such as the reaction temperature $\left(\mathrm{X}_{1}\right)$, the contact time $\left(\mathrm{X}_{2}\right)$, the concentration of phosphoric acid $\left(\mathrm{X}_{3}\right)$, the ratio of acid solution volume to 
$\operatorname{DCV}\left(\mathrm{X}_{4}\right)$, MDCV biosorption capacity $\left(\mathrm{Y}_{1}\right)$, and residual $\operatorname{MDCV}\left(\mathrm{Y}_{2}\right)$, determined by the design of experiments, are shown in Table 14. The number of 27 experiments including 8 axial points $(\alpha$ $=1$ ) and 3 central points were considered in CCD. About $0.1 \mathrm{~g}$ of DCV was treated under each designed experimental conditions. Finally, MDCV was filtered and neutralized with deionized water and $0.1 \mathrm{M}$ sodium carbonate. It was then dried at $50^{\circ} \mathrm{C}$ for $24 \mathrm{hr}$ and crushed into fine particles. The MDCV biosorption capacities and the residual MDCV were considered as experimental design responses. The residual of MDCV was calculated using Equation 4:

Residual MDCV $(\%)=\frac{m_{2}}{m_{1}} \times 100$

Where $\mathrm{m}_{1}$ and $\mathrm{m}_{2}$ are the mass of DCV (mg) before and after acid treatment, respectively.

Table (14) - Levels of coded and uncoded variables for the MDCV biosorption capacity and residual MDCV

\begin{tabular}{ccccc}
\hline Variable & Name & \multicolumn{3}{c}{ Range of levels } \\
\cline { 3 - 5 } & & -1 & 0 & 1 \\
\hline $\mathrm{X}_{1}$ & The temperature of the reaction, $\mathrm{T},{ }^{\circ} \mathrm{C}$ & 30 & 50 & 70 \\
$\mathrm{X}_{2}$ & The contact time of DCV with acid, $\mathrm{t}, \mathrm{hr}$ & 3 & 6 & 9 \\
$\mathrm{X}_{3}$ & The concentration of acid, $\mathrm{C}_{\mathrm{A}}, \mathrm{mol} / \mathrm{L}$ & 2 & 4 & 6 \\
$\mathrm{X}_{4}$ & The ratio of acid volume to DCV, $/ \mathrm{W}, \mathrm{mL} / \mathrm{g}$ & 30 & 50 & 70 \\
\hline $\mathrm{Y}_{1}$ & MDCV biosorption capacity, $\mathrm{q}_{\mathrm{MDCV}}, \mathrm{mg} / \mathrm{g}$ & & \\
$\mathrm{Y}_{2}$ & Residual MDCV, $\mathrm{PP}_{\mathrm{MDCV}}, \%$ & & \\
\hline
\end{tabular}

Considering the last responses, the regression, and the variance analysis (ANOVA) were done using Minitab-18 software. Optimal conditions were calculated in the maximum amount of both responses and DCV was modified in those conditions [33].

\section{$\mathrm{MDCV} / \mathrm{Fe}_{3} \mathrm{O}_{4}$ preparation}

Synthesis of $\mathrm{MDCV} / \mathrm{Fe}_{3} \mathrm{O}_{4}$ particles were performed by the co-precipitation method [86, 87]. To do that, about $0.1 \mathrm{~g}$ of MCDV was stirred with $100 \mathrm{~mL}$ of deionized water for 5 minutes and then sonicated with the frequency of $28 \mathrm{kHz}$ at room temperature for 30 minutes. Sonicated solution was added to $100 \mathrm{~mL}$ of an aqueous solution containing $\mathrm{FeSO}_{4} \cdot 7 \mathrm{H}_{2} \mathrm{O}$ and $\mathrm{FeCl}_{3} \cdot 6 \mathrm{H}_{2} \mathrm{O}$ with a $1: 2$ $\mathrm{M}$ ratio. The mixture was stirred under a nitrogen atmosphere at $85^{\circ} \mathrm{C}$ and $250 \mathrm{rpm}$. After 15 
minutes, about $10 \mathrm{~mL}$ of ammonia was added dropwise to the system for setting the $\mathrm{pH}$ about 9 . The reaction continued for an hour. The $\mathrm{MDCV} / \mathrm{Fe}_{3} \mathrm{O}_{4}$ particles were separated using an external magnet and washed several times with deionized water to reach $\mathrm{pH}$. Finally, $\mathrm{MDCV} / \mathrm{Fe}_{3} \mathrm{O}_{4}$ particles were dried at $50^{\circ} \mathrm{C}$ for $24 \mathrm{hr}$ and then powdered by mortar $[32,88]$.

\section{Biosorption analysis}

The biosorption of $\mathrm{MB}$ on $\mathrm{MDCV} / \mathrm{Fe}_{3} \mathrm{O}_{4}$ was performed in a batch using an incubator at $200 \mathrm{rpm}$. The effect of variables such as temperature $\left(\mathrm{X}_{1}\right)$, contact time $\left(\mathrm{X}_{2}\right)$, biosorbent dosage $\left(\mathrm{X}_{3}\right)$, initial concentration of $\mathrm{MB}\left(\mathrm{X}_{4}\right)$, and $\mathrm{pH}\left(\mathrm{X}_{5}\right)$ were investigated. $\mathrm{NaOH}$ and $\mathrm{HCl} 0.1 \mathrm{M}$ were used to regulate the $\mathrm{pH}$. The experiments were performed using the CCD by RSM involving 29 runs with 3 central points and 10 axial points $(\alpha=1)$. The coded and uncoded conditions specified by the experimental design are shown in Table 15.

Table (15) - Levels of coded and uncoded biosorption variables using MDCV/Fe $e_{3} \mathrm{O}_{4}$ as a biosorbent

\begin{tabular}{ccccc}
\hline Variable & Name & \multicolumn{3}{c}{ Range of levels } \\
\cline { 2 - 4 } & & -1 & 0 & 1 \\
\hline $\mathrm{X}_{1}$ & Temperature, $\mathrm{T},{ }^{\circ} \mathrm{C}$ & 5 & 25 & 45 \\
$\mathrm{X}_{2}$ & Contact time, $\mathrm{t}, \mathrm{min}$ & 30 & 60 & 90 \\
$\mathrm{X}_{3}$ & Biosorbent dosage, $\mathrm{m}, \mathrm{mg}$ & 15 & 30 & 45 \\
$\mathrm{X}_{4}$ & Initial concentration of $\mathrm{MB}, \mathrm{C}_{0}, \mathrm{mg} / \mathrm{L}$ & 20 & 60 & 100 \\
$\mathrm{X}_{5}$ & $\mathrm{pH}$ & 5 & 7 & 9 \\
\hline $\mathrm{Y}$ & biosorption capacity of $\mathrm{MDCV} / \mathrm{Fe}_{3} \mathrm{O}_{4}$, & & \\
& $\mathrm{q}_{\mathrm{MDCV} / \mathrm{Fe}_{3} \mathrm{O}_{4}}, \mathrm{mg} / \mathrm{L}$ & & \\
\hline
\end{tabular}

The final concentration of MB was obtained using a UV-Visible spectrophotometer at $\lambda_{\max }=665 \mathrm{~nm}[89]$. Biosorption capacity $(\mathrm{mg} / \mathrm{g})$ and removal percentage $(\%)$ were calculated based on the following Equations:

$$
\begin{aligned}
& q_{t}=\frac{\left(C_{0}-C_{t}\right) \times V}{m} \\
& R=\frac{\left(C_{0}-C_{t}\right) \times 100}{C_{0}}
\end{aligned}
$$


Where $C_{0}$ and $C_{t}$ are the initial and final concentrations of $M B(m g / L)$, respectively. $V$ is the volume of the dye pollutant $(\mathrm{L})$ and $\mathrm{m}$ is the biosorbent dosage $(\mathrm{g})$.

Regression, and variance analysis (ANOVA) of the biosorption capacity of $\mathrm{MDCV} / \mathrm{Fe}_{3} \mathrm{O}_{4}$ were done using Minitab-18 software.

\section{Statistical analysis}

The design of the experiments was done by using the central compound design (CCD) of the response surface methodology (RSM). The responses were considered based on the quadratic functions with the interaction of the variables affecting them according to Equation 7. Also, the levels of variables are based on Equation 8 [90].

$y=\beta_{0}+\sum_{i=1}^{k} \beta_{i} x_{i}+\sum_{i=1}^{k} \beta_{i i} x_{i}^{2}+\sum_{1 \leq i \leq j}^{k} \beta_{i j} x_{i} x_{j}+\varepsilon$

$x_{i}=\left(\frac{z_{i}-z_{i}^{0}}{\Delta z_{i}}\right) \beta_{d}$

Where $\beta_{\mathrm{i}}$ shows the coefficients of the parameters of the quadratic function, $\mathrm{z}_{\mathrm{i}}$ and $\mathrm{x}_{\mathrm{i}}$ are real and coded values, respectively. $\Delta \mathrm{z}_{\mathrm{i}}$ is the distance between the value of the center point and the next or previous levels. $\beta_{\mathrm{d}}$ is the major coded value for each variable. $z_{i}^{0}$ is the real value of the center point.

The relation between the total sum of the square $\left(\mathrm{SS}_{\text {Total }}\right)$, the sum of the square due to regression $\left(\mathrm{SS}_{\mathrm{Reg}}\right)$, and errors $\left(\mathrm{SS}_{\mathrm{Error}}\right)$ is based on Equation 9. The equations for calculating the sum of squares and the mean sum of squares of the data are shown in Table 16. The matching of the regression model and experimental data is determined by using the calculated Fisher distribution $\left(\mathrm{F}_{\text {calc. }}\right)$, the critical Fisher distribution $\left(\mathrm{F}_{\mathrm{c}}\right)$, the probability value (P-value), and the adjusted determination coefficient $\left(\mathrm{R}_{\mathrm{adj}}^{2}\right.$ ), as shown in Equations 10-13 [90]. The statistical calculations are also based on the probability of $95 \%(\alpha=0.05)$.

$$
\begin{aligned}
& S S_{\text {Tot }}=S S_{\text {Reg }}+S S_{\text {Error }} \\
& F_{\text {calc. }}=\frac{M S S_{\text {Reg }}}{M S S_{\text {Error }}} \\
& F_{c}=F_{\alpha, d f_{\text {Model }}, d f_{\text {Error }}}
\end{aligned}
$$




$$
\begin{aligned}
& P-\text { value }=2 \times \int_{F_{c}}^{+\infty} f(F) d f \\
& R_{a d j}^{2}=1-\frac{S S_{\text {Error }} / n-p}{S S_{\text {Total }} / n-1}
\end{aligned}
$$

Where $\mathrm{n}$ and $\mathrm{p}$ are the numbers of observations and parameters of the model, respectively.

Table (16) - Analysis of variance for a fitted mathematical model to an experimental data using multiple regression

\begin{tabular}{|c|c|c|c|}
\hline Variation source & Sum of the square & Degree of freedom & Mean sum of the square \\
\hline Regression & $S S_{R e g}=\sum_{j}^{J} \sum_{i}^{I_{j}}\left(\hat{y}_{i}-\bar{y}\right)^{2}$ & $\mathrm{p}-1$ & $M S S_{\text {Reg }}=\frac{S S_{\text {Reg }}}{p-1}$ \\
\hline Error & $S S_{\text {Error }}=\sum_{j}^{J} \sum_{i}^{I_{j}}\left(y_{i j}-\bar{y}_{i}\right)^{2}(16)$ & $n-p$ & $M S S_{\text {Error }}=\frac{S S_{\text {Error }}}{n-p}(17)$ \\
\hline Total & $S S_{\text {Total }}=\sum_{j}^{J} \sum_{i}^{I_{j}}\left(y_{i j}-\bar{y}\right)^{2}$ & $n-1$ & - \\
\hline
\end{tabular}
[90]

$\mathrm{n}$ : Number of observations, $\mathrm{p}$ : Number of the parameters of the model, $\hat{y}_{i}$ : Estimated value for the level i by the model, $\bar{y}$ : Mean of overall data, $y_{i j}$ : Replication in each level, $\bar{y}_{i}$ : Mean of replicated data in the same conditions

\section{Biosorption kinetics}

Kinetic studies were performed to evaluate the reaction rate, equilibrium time, equilibrium capacity, and biosorption process behavior. For this purpose, the models such as pseudo-secondorder and intraparticle diffusion were used according to Equations 19-20, which are shown in Table 17.

Table (17) - Kinetic models using in this study

\begin{tabular}{cccccc}
\hline Model & Equation & Plots & Parameters & Ref. \\
\hline Pseudo-second-order & $\frac{t}{q_{t}}=\frac{1}{k_{2} q_{e}^{2}}+\frac{t}{q_{e}}$ & $(19)$ & $\frac{\mathrm{t}}{\mathrm{q}_{\mathrm{t}}} \mathrm{vs.t}$ & $\begin{array}{c}\text { Calculating } \mathrm{q}_{\mathrm{e}} \text { and } \mathrm{k}_{2} \text { through } \\
\text { the slope and intercept }\end{array}$ & [91] \\
Intraparticle diffusion & $q_{t}=k_{i d} t^{0.5}+C(20)$ & $\mathrm{q}_{\mathrm{t}}$ vs. $\mathrm{t}^{0.5}$ & $\begin{array}{c}\text { Calculating } \mathrm{k}_{\mathrm{id}} \text { and C through } \\
\text { the slope and intercept }\end{array}$ & \\
& & & & \\
& & & & \\
\end{tabular}

\section{Biosorption isotherms}


The trend of equilibrium biosorption capacity $\left(\mathrm{q}_{\mathrm{e}}\right)$ according to the equilibrium concentration of $\mathrm{MB}\left(\mathrm{C}_{\mathrm{e}}\right)$ is investigated using biosorption equilibrium isotherms. The datasets were calculated in different initial concentrations of $\mathrm{MB}$ at constant temperatures over time. In each step, $\mathrm{q}_{\mathrm{e}}$ was calculated using the biosorption capacity of $\mathrm{MDCV} / \mathrm{Fe}_{3} \mathrm{O}_{4}$. Then $\mathrm{C}_{\mathrm{e}}$ was calculated using $\mathrm{C}_{0}$ and $\mathrm{q}_{\mathrm{e}}$ at each run. Langmuir, Freundlich, and Temkin isotherms were examined using Equations 2124 reported in Table 18 [67, 93, 94].

Table (18) - Isotherm models using in this study

\begin{tabular}{|c|c|c|c|c|}
\hline Model & Equation & Plots & Parameters & Ref. \\
\hline \multirow[t]{2}{*}{ Langmuir } & $\frac{C_{e}}{q_{e}}=\frac{1}{K_{L} q_{m}}+\frac{C_{e}}{q_{m}}$ & $\frac{\mathrm{C}_{\mathrm{e}}}{\mathrm{q}_{\mathrm{e}}}$ vs. $\mathrm{C}_{\mathrm{e}}$ & $\begin{array}{c}\text { Calculating } \mathrm{q}_{\mathrm{m}} \text { and } \mathrm{K}_{\mathrm{L}} \\
\text { through the slope and } \\
\text { intercept }\end{array}$ & [95] \\
\hline & $R_{L}=\frac{1}{1+K_{L} C_{0}}$ & $\mathrm{R}_{\mathrm{L}}$ vs. $\mathrm{C}_{0}$ & $\mathrm{R}_{\mathrm{L}}$ & [92] \\
\hline Freundlich & $\log q_{e}=\log K_{F}+\frac{1}{n} \log C_{e}$ & $\log \mathrm{q}_{\mathrm{e}} \mathrm{vs} . \log \mathrm{C}_{\mathrm{e}}$ & $\begin{array}{l}\text { Calculating } \mathrm{n} \text { and } \mathrm{K}_{\mathrm{F}} \\
\text { through the slope and } \\
\text { intercept }\end{array}$ & [96] \\
\hline Temkin & $q_{e}=\frac{R T}{b_{T}} \ln \left(K_{T}\right)+\frac{R T}{b_{T}} \ln \left(C_{e}\right)(24)$ & $\mathrm{q}_{\mathrm{e}} \mathrm{vs} \cdot \ln \left(\mathrm{C}_{\mathrm{e}}\right)$ & $\begin{array}{c}\text { Calculating } \mathrm{b}_{\mathrm{T}} \text { and } \mathrm{K}_{\mathrm{T}} \\
\text { through the slope and } \\
\text { intercept }\end{array}$ & [97] \\
\hline
\end{tabular}

\section{Biosorption thermodynamics}

The thermodynamics of biosorption of $\mathrm{MB}$ on $\mathrm{MDCV} / \mathrm{Fe}_{3} \mathrm{O}_{4}$ were studied at temperatures of 278, 298 , and $317 \mathrm{~K}$. Gibbs free energy change $(\Delta \mathrm{G})$, enthalpy change $(\Delta \mathrm{H})$, and entropy change $(\Delta S)$ were calculated according to the following Equations:

$$
\begin{aligned}
& \Delta G^{\circ}=\Delta H^{\circ}-T \Delta S^{\circ} \\
& \Delta G^{\circ}=-R T \ln \left(K_{C}\right) \\
& \ln \left(K_{C}\right)=\frac{\Delta S^{\circ}}{R}-\frac{\Delta H^{\circ}}{R T} \\
& K_{C}=\frac{K_{F} \rho}{1000}\left(\frac{10^{6}}{\rho}\right)^{\left(1-\frac{1}{n}\right)}
\end{aligned}
$$


In the above equations, $R$ is the gas constant (J/mol.K), T is the temperature of the process $(\mathrm{K}), \rho$

is water density $(\mathrm{g} / \mathrm{mL}), \mathrm{K}_{\mathrm{F}}$ is the Freundlich constant $\left(\left(\frac{\mathrm{mg}}{\mathrm{g}}\right)\left(\frac{\mathrm{mg}}{\mathrm{L}}\right)^{1 / \mathrm{n}}\right), \mathrm{n}$ is the Freundlich constant too, and $\mathrm{K}_{\mathrm{c}}$ is the equilibrium constant. Equation 27 refers to the Van't Hoff plot of $\ln \mathrm{K}_{\mathrm{c}}$ versus $1 / \mathrm{T}[98,99]$.

\section{Biosorbent characterization}

Several analyses were performed to determine the morphology and specifications of four samples of $\mathrm{RCV}, \mathrm{DCV}, \mathrm{MDCV}$, and $\mathrm{MDCV} / \mathrm{Fe}_{3} \mathrm{O}_{4}$. The X-ray Diffraction Patterns (XRD) was done by PW1730, PHILIPS, Netherland with $\mathrm{Cu}-\mathrm{ka}$ radiation and wavelength of $1.54056 \mathrm{~A}^{\circ}$, at $40 \mathrm{kV}$ in the range of $10-80^{\circ}$ with a scanning speed of $0.05^{\circ}$ s. Fourier Transform Infrared Spectroscopy (FTIR) AVATAR, Thermo, USA was used in the range of 400 to $4000 \mathrm{~cm}^{-1}$ to identify functional groups. Phase identification, percentage of elements, and morphology of samples were performed using Scanning Electron Microscopy (SEM) and Energy-Dispersive X-ray Spectroscopy (EDS) analyses by MIRA III, TESCAN, Czech Republic. Brunauer-Emmett-Teller (BET) analysis was performed using the liquid nitrogen adsorption-desorption process at $77 \mathrm{~K}$ by BELSORP MINI II, BEL, Japan to determine the porosity of the structure. Vibrating Sample Magnetometer (VSM) analysis by Meghnatis Daghigh Kavir Co., Iran at -15000 to 15000 Oe was used to study magnetic properties. The UV-Visible spectrophotometer was also used to determine the MB concentration.

\footnotetext{
Abbreviations

RCV: Raw Chlorella vulgaris, DCV: Defatted Chlorella vulgaris, MDCV: Modified defatted Chlorella vulgaris, $\mathrm{MDCV} / \mathrm{Fe}_{3} \mathrm{O}_{4}$ : Magnetic modified defatted Chlorella vulgaris, $\mathrm{Fe}_{3} \mathrm{O}_{4}$ : Iron oxide particles, MB: Methylene blue, CCD: Central composite design, RSM: Response surface methodology, $\mathrm{q}_{\mathrm{MDCV}}$ : MDCV biosorption capacity, $\mathrm{RP}_{\mathrm{MDCV}}$ : Residual MDCV, $\mathrm{q}_{\mathrm{MDCV} / \mathrm{Fe}_{3} \mathrm{O}_{4}}$ : Biosorption capacity of $\mathrm{MDCV} / \mathrm{Fe}_{3} \mathrm{O}_{4}, \mathrm{q}_{\mathrm{t}}$ : Biosorption capacity, $\mathrm{C}_{0}$ : Initial concentrations of MB, $\mathrm{C}_{\mathrm{t}}$ : Final concentrations of MB, ANOVA: Analysis of variance, $\mathrm{SS}_{\mathrm{Total}}$ : Total sum of the square, $\mathrm{SS}_{\mathrm{Reg}}$ : Sum of the square of regression, $\mathrm{SS}_{\mathrm{Error}}$ : $\mathrm{Sum}$ of the square of error, $\mathrm{F}_{\text {calc. }}$ : Calculated Fisher distribution, $F_{c}$ : Critical Fisher distribution, P-value: Probability value, $R_{a d j}^{2}$ : Adjusted determination coefficient, $\mathrm{q}_{\mathrm{e}}$ : Equilibrium biosorption capacity, $\mathrm{C}_{\mathrm{e}}$ : Equilibrium concentration of $\mathrm{MB}, \Delta \mathrm{G}$ : Gibbs free energy change, $\Delta \mathrm{H}$ : Enthalpy change, $\Delta$ S: Entropy change, XRD: X-ray Diffraction Patterns, FTIR: Fourier Transform Infrared Spectroscopy, SEM: Scanning Electron Microscopy, EDS: Energy-Dispersive X-ray Spectroscopy, BET: Brunauer-Emmett-Teller, VSM: Vibrating Sample Magnetometer, BJH: Barrett-Joyner-Halenda, IUPAC: International Union of Pure and Applied Chemistry.
} 


\section{Acknowledgments}

We would like to thank the university of Tehran.

\section{Authors' contributions}

Naziri S. wrote the main manuscript text and was involved in all tests directly. Salehi Z. was a chemical engineering supervisor of the research. She also edited the manuscript, sponsored the study, and made all the arrangements.

\section{Funding}

It was not a funded project.

\section{Availability of data and materials}

All data generated or analyzed during this study are included in the manuscript.

\section{Ethics approval and consent to participate}

Not applicable.

\section{Consent for publication}

All authors are agree with submission to journal of Biotechnology for Biofuel.

\section{Competing interests}

There are no competing interests associated with this manuscript.

\section{Author details}

${ }^{1}$ Department of Chemical Engineering, School of Chemical Engineering, College of Engineering, University of Tehran, Tehran, Iran. ${ }^{2}$ Department of Biotechnology Engineering, School of Chemical Engineering, College of Engineering, University of Tehran, Tehran, Iran

\section{References}

[1] M. Goswami and P. Phukan, "Enhanced adsorption of cationic dyes using sulfonic acid modified activated carbon," Journal of Environmental Chemical Engineering, vol. 5, no. 4, pp. 3508-3517, 2017.

[2] A. H. Shalla, M. A. Bhat, and Z. Yaseen, "Hydrogels for removal of recalcitrant organic dyes: A conceptual overview," Journal of environmental chemical engineering, vol. 6, no. 5, pp. 5938-5949, 2018.

[3] J. Hoslett, H. Ghazal, N. Mohamad, and H. Jouhara, "Removal of methylene blue from aqueous solutions by biochar prepared from the pyrolysis of mixed municipal discarded material," Science of The Total Environment, vol. 714, p. 136832, 2020.

[4] G. O. El-Sayed, "Removal of methylene blue and crystal violet from aqueous solutions by palm kernel fiber," Desalination, vol. 272, no. 1-3, pp. 225-232, 2011. 
[5] M. Rafatullah, O. Sulaiman, R. Hashim, and A. Ahmad, "Adsorption of methylene blue on low-cost adsorbents: a review," Journal of hazardous materials, vol. 177, no. 1-3, pp. 70-80, 2010.

[6] J. Ma, X. Tang, Y. He, Y. Fan, and J. Chen, "Robust stable MoS2/GO filtration membrane for effective removal of dyes and salts from water with enhanced permeability," Desalination, vol. 480, p. 114328, 2020.

[7] T. A. Aragaw, "Utilizations of electro-coagulated sludge from wastewater treatment plant data as an adsorbent for direct red 28 dye removal," Data in brief, vol. 28, p. 104848, 2020.

[8] R. Melo, E. B. Neto, S. Nunes, T. C. Dantas, and A. D. Neto, "Removal of Reactive Blue 14 dye using micellar solubilization followed by ionic flocculation of surfactants," Separation And Purification Technology, vol. 191, pp. 161-166, 2018.

[9] V. S. Garcia, J. M. Rosa, and S. I. Borrely, "Toxicity and color reduction of a textile effluent containing reactive red 239 dye by electron beam irradiation," Radiation Physics and Chemistry, vol. 172, p. 108765, 2020.

[10] B. O. Unal et al., "Adsorption and Fenton oxidation of azo dyes by magnetite nanoparticles deposited on a glass substrate," Journal of Water Process Engineering, vol. 32, p. 100897, 2019.

[11] S. P. Ghuge and A. K. Saroha, "Catalytic ozonation of dye industry effluent using mesoporous bimetallic Ru-Cu/SBA-15 catalyst," Process Safety and Environmental Protection, vol. 118, pp. 125-132, 2018.

[12] B. Bharathiraja, I. A. E. Selvakumari, J. Iyyappan, and S. Varjani, "Itaconic acid: an effective sorbent for removal of pollutants from dye industry effluents," Current Opinion in Environmental Science \& Health, vol. 12, pp. 6-17, 2019.

[13] N. D. Shooto, C. S. Nkutha, N. R. Guilande, and E. B. Naidoo, "Pristine and modified mucuna beans adsorptive studies of toxic lead ions and methylene blue dye from aqueous solution," South African Journal of Chemical Engineering, vol. 31, pp. 33-43, 2020.

[14] A. Stavrinou, C. Aggelopoulos, and C. Tsakiroglou, "Exploring the adsorption mechanisms of cationic and anionic dyes onto agricultural waste peels of banana, cucumber and potato: Adsorption kinetics and equilibrium isotherms as a tool," Journal of environmental chemical engineering, vol. 6, no. 6, pp. 6958$6970,2018$.

[15] M. Karthika and M. Vasuki, "Adsorption of Alizarine Red-S Dye from Aqueous Solution by Sago Waste: Resolution of Isotherm, Kinetics and Thermodynamics," Materials Today: Proceedings, vol. 14, pp. 358$367,2019$.

[16] P. V. Rao, P. Pydiraju, V. Madhuri, S. Vineeth, S. Rahimuddin, and M. Vangalapati, "Removal of indigo carmine dye from aqueous solution by adsorption on biomass of Grevillea Robusta leaves," Materials Today: Proceedings, 2020.

[17] Z. Jiang and D. Hu, "Molecular mechanism of anionic dyes adsorption on cationized rice husk cellulose from agricultural wastes," Journal of Molecular Liquids, vol. 276, pp. 105-114, 2019.

[18] W. Tsai, J. Yang, C. Lai, Y. Cheng, C. Lin, and C. Yeh, "Characterization and adsorption properties of eggshells and eggshell membrane," Bioresource technology, vol. 97, no. 3, pp. 488-493, 2006. 
[19] R. M. Moghazy, A. Labena, and S. Husien, "Eco-friendly complementary biosorption process of methylene blue using micro-sized dried biosorbents of two macro-algal species (Ulva fasciata and Sargassum dentifolium): Full factorial design, equilibrium, and kinetic studies," International journal of biological macromolecules, vol. 134, pp. 330-343, 2019.

[20] A. L. D. da Rosa, E. Carissimi, G. L. Dotto, H. Sander, and L. A. Feris, "Biosorption of rhodamine B dye from dyeing stones effluents using the green microalgae Chlorella pyrenoidosa," Journal of Cleaner Production, vol. 198, pp. 1302-1310, 2018.

[21] F. Afshariani and A. Roosta, "Experimental study and mathematical modeling of biosorption of methylene blue from aqueous solution in a packed bed of microalgae Scenedesmus," Journal of Cleaner Production, vol. 225, pp. 133-142, 2019.

[22] D. C. Alves, B. B. Coseglio, L. A. Pinto, and T. R. Cadaval Jr, "Development of Spirulina/chitosan foam adsorbent for phenol adsorption," Journal of Molecular Liquids, p. 113256, 2020.

[23] M. A. Maksoud, A. M. Elgarahy, C. Farrell, H. Ala'a, D. W. Rooney, and A. I. Osman, "Insight on water remediation application using magnetic nanomaterials and biosorbents," Coordination Chemistry Reviews, vol. 403, p. 213096, 2020.

[24] C. Safi, B. Zebib, O. Merah, P.-Y. Pontalier, and C. Vaca-Garcia, "Morphology, composition, production, processing and applications of Chlorella vulgaris: A review," Renewable and Sustainable Energy Reviews, vol. 35, pp. 265-278, 2014.

[25] H. Sati, M. Mitra, S. Mishra, and P. Baredar, "Microalgal lipid extraction strategies for biodiesel production: A review," Algal Research, vol. 38, p. 101413, 2019.

[26] J. T. da Fontoura, G. S. Rolim, B. Mella, M. Farenzena, and M. Gutterres, "Defatted microalgal biomass as biosorbent for the removal of Acid Blue 161 dye from tannery effluent," Journal of environmental chemical engineering, vol. 5, no. 5, pp. 5076-5084, 2017.

[27] E. Baldikova et al., "Use of waste Japonochytrium sp. biomass after lipid extraction as an efficient adsorbent for triphenylmethane dye applied in aquaculture," Biomass Conversion and Biorefinery, vol. 9, no. 3, pp. 479-488, 2019.

[28] H. Shao, Y. Li, L. Zheng, T. Chen, and J. Liu, "Removal of methylene blue by chemically modified defatted brown algae Laminaria japonica," Journal of the Taiwan Institute of Chemical Engineers, vol. 80, pp. 525532, 2017.

[29] E. Daneshvar, A. Vazirzadeh, A. Niazi, M. Sillanpää, and A. Bhatnagar, "A comparative study of methylene blue biosorption using different modified brown, red and green macroalgae-Effect of pretreatment," Chemical Engineering Journal, vol. 307, pp. 435-446, 2017.

[30] R. Angelova, E. Baldikova, K. Pospiskova, Z. Maderova, M. Safarikova, and I. Safarik, "Magnetically modified Sargassum horneri biomass as an adsorbent for organic dye removal," Journal of Cleaner Production, vol. 137, pp. 189-194, 2016. 
[31] S. Mullerova, E. Baldikova, J. Prochazkova, K. Pospiskova, and I. Safarik, "Magnetically modified macroalgae Cymopolia barbata biomass as an adsorbent for safranin O removal," Materials Chemistry and Physics, vol. 225, pp. 174-180, 2019.

[32] R. Foroutan, R. Mohammadi, J. Razeghi, and B. Ramavandi, "Performance of algal activated carbon/Fe3O4 magnetic composite for cationic dyes removal from aqueous solutions," Algal Research, vol. 40, p. 101509, 2019.

[33] M. T. Bai and P. Venkateswarlu, "Optimization studies for lead biosorption on Sargassum tenerrimum (Brown Algae) using experimental design: Response Surface Methodology," Materials Today: Proceedings, vol. 18, pp. 4290-4298, 2019.

[34] G. Falini, S. Fermani, M. Gazzano, and A. Ripamonti, "Structure and morphology of synthetic magnesium calcite," Journal of Materials Chemistry, vol. 8, no. 4, pp. 1061-1065, 1998.

[35] P. Althoff, "Structural refinements of dolomite and a magnesian calcite and implications for dolomite formation in the marine environment," American Mineralogist, vol. 62, no. 7-8, pp. 772-783, 1977.

[36] S. Sasaki, "Radial distribution of electron density in magnetite, Fe3O4," Acta Crystallographica Section B: Structural Science, vol. 53, no. 5, pp. 762-766, 1997.

[37] A. C. Khorasani and S. A. Shojaosadati, "Magnetic pectin-Chlorella vulgaris biosorbent for the adsorption of dyes," Journal of Environmental Chemical Engineering, vol. 7, no. 3, p. 103062, 2019.

[38] T. Driver, A. K. Bajhaiya, J. W. Allwood, R. Goodacre, J. K. Pittman, and A. P. Dean, "Metabolic responses of eukaryotic microalgae to environmental stress limit the ability of FT-IR spectroscopy for species identification," Algal research, vol. 11, pp. 148-155, 2015.

[39] K. Maliutina, A. Tahmasebi, and J. Yu, "The transformation of nitrogen during pressurized entrained-flow pyrolysis of Chlorella vulgaris," Bioresource technology, vol. 262, pp. 90-97, 2018.

[40] Y. Wang, Y. Zhang, S. Li, W. Zhong, and W. Wei, "Enhanced methylene blue adsorption onto activated reed-derived biochar by tannic acid," Journal of Molecular Liquids, vol. 268, pp. 658-666, 2018.

[41] Y. Peng et al., "Enhanced Hg (II) adsorption by monocarboxylic-acid-modified microalgae residuals in simulated and practical industrial wastewater," Energy \& Fuels, vol. 32, no. 4, pp. 4461-4468, 2018.

[42] Y. Lebron, V. Moreira, and L. Santos, "Studies on dye biosorption enhancement by chemically modified Fucus vesiculosus, Spirulina maxima and Chlorella pyrenoidosa algae," Journal of Cleaner Production, vol. 240, p. 118197, 2019.

[43] P. L. Gupta, H. Jung, D. Tiwari, S.-H. Kong, and S.-M. Lee, "Insight into the mechanism of Cd (II) and Pb (II) removal by sustainable magnetic biosorbent precursor to Chlorella vulgaris," Journal of the Taiwan Institute of Chemical Engineers, vol. 71, pp. 206-213, 2017.

[44] A. Asiedu, R. Davis, and S. Kumar, "Catalytic transfer hydrogenation and characterization of flash hydrolyzed microalgae into hydrocarbon fuels production (jet fuel)," Fuel, vol. 261, p. 116440, 2020.

[45] S. Lowell, J. E. Shields, M. A. Thomas, and M. Thommes, Characterization of porous solids and powders: surface area, pore size and density. Springer Science \& Business Media, 2012. 
[46] K. Hwang et al., "Chlamydomonas angulosa (Green Alga) and Nostoc commune (Blue-Green Alga) microalgae-cellulose composite aerogel beads: manufacture, physicochemical characterization, and Cd (II) adsorption," Materials, vol. 11, no. 4, p. 562, 2018.

[47] H. Qiu, C. Luo, M. Sun, F. Lu, L. Fan, and X. Li, "A chemiluminescence sensor for determination of epinephrine using graphene oxide-magnetite-molecularly imprinted polymers," Carbon, vol. 50, no. 11, pp. 4052-4060, 2012.

[48] M. Govarthanan, C.-H. Jeon, Y.-H. Jeon, J.-H. Kwon, H. Bae, and W. Kim, "Non-toxic nano approach for wastewater treatment using Chlorella vulgaris exopolysaccharides immobilized in iron-magnetic nanoparticles," International Journal of Biological Macromolecules, vol. 162, pp. 1241-1249, 2020.

[49] S. Ghosh, A. Badruddoza, M. Uddin, and K. Hidajat, "Adsorption of chiral aromatic amino acids onto carboxymethyl- $\beta$-cyclodextrin bonded $\mathrm{Fe} 3 \mathrm{O} 4 / \mathrm{SiO} 2$ core-shell nanoparticles," Journal of colloid and interface science, vol. 354, no. 2, pp. 483-492, 2011.

[50] S. Khammar, N. Bahramifar, and H. Younesi, "Optimization using the response surface methodology for adsorption of polychlorinated biphenyls (PCBs) from transformer oil by magnetic CMCD-Fe3O4@ $\mathrm{SiO} 2$ nanoparticles," Materials Chemistry and Physics, p. 123195, 2020.

[51] N. E.-A. El-Naggar and N. H. Rabei, "Bioprocessing optimization for efficient simultaneous removal of methylene blue and nickel by Gracilaria seaweed biomass," Scientific Reports, vol. 10, no. 1, pp. 1-21, 2020.

[52] N. Kumari and R. K. Singh, "Biofuel and co-products from algae solvent extraction," Journal of environmental management, vol. 247, pp. 196-204, 2019.

[53] P. Sharma, N. Hussain, D. J. Borah, and M. R. Das, "Kinetics and adsorption behavior of the methyl blue at the graphene oxide/reduced graphene oxide nanosheet-water interface: a comparative study," Journal of Chemical \& Engineering Data, vol. 58, no. 12, pp. 3477-3488, 2013.

[54] P. Nautiyal, K. Subramanian, and M. Dastidar, "Adsorptive removal of dye using biochar derived from residual algae after in-situ transesterification: alternate use of waste of biodiesel industry," Journal of Environmental Management, vol. 182, pp. 187-197, 2016.

[55] F. Luo, Y. Liu, X. Li, Z. Xuan, and J. Ma, "Biosorption of lead ion by chemically-modified biomass of marine brown algae Laminaria japonica," Chemosphere, vol. 64, no. 7, pp. 1122-1127, 2006.

[56] S. Hadjoudja, V. Deluchat, and M. Baudu, "Cell surface characterisation of Microcystis aeruginosa and Chlorella vulgaris," Journal of colloid and interface science, vol. 342, no. 2, pp. 293-299, 2010.

[57] M. Ahmed, P. Okoye, E. Hummadi, and B. Hameed, "High-performance porous biochar from the pyrolysis of natural and renewable seaweed (Gelidiella acerosa) and its application for the adsorption of methylene blue," Bioresource technology, vol. 278, pp. 159-164, 2019.

[58] S. Rangabhashiyam and P. Balasubramanian, "Characteristics, performances, equilibrium and kinetic modeling aspects of heavy metal removal using algae," Bioresource Technology Reports, vol. 5, pp. 261$279,2019$. 
[59] F. Mashkoor and A. Nasar, "Magsorbents: Potential candidates in wastewater treatment technology-A review on the removal of methylene blue dye," Journal of Magnetism and Magnetic Materials, vol. 500, p. 166408, 2020.

[60] A. Selvakumar and S. Rangabhashiyam, "Biosorption of Rhodamine B onto novel biosorbents from Kappaphycus alvarezii, Gracilaria salicornia and Gracilaria edulis," Environmental Pollution, vol. 255, p. 113291, 2019.

[61] A. König-Péter, F. Kilár, A. Felinger, and T. Pernyeszi, "Biosorption characteristics of Spirulina and Chlorella cells to accumulate heavy metals," Journal of the Serbian Chemical Society, vol. 80, no. 3, pp. 407419, 2015.

[62] T. A. Khan and E. A. Khan, "Removal of basic dyes from aqueous solution by adsorption onto binary ironmanganese oxide coated kaolinite: non-linear isotherm and kinetics modeling," Applied Clay Science, vol. 107, pp. 70-77, 2015.

[63] F.-M. Pellera et al., "Adsorption of $\mathrm{Cu}$ (II) ions from aqueous solutions on biochars prepared from agricultural by-products," Journal of Environmental Management, vol. 96, no. 1, pp. 35-42, 2012.

[64] A. Pholosi, E. B. Naidoo, and A. E. Ofomaja, "Intraparticle diffusion of Cr (VI) through biomass and magnetite coated biomass: A comparative kinetic and diffusion study," South African Journal of Chemical Engineering, vol. 32, pp. 39-55, 2020.

[65] M. Arami, N. Y. Limaee, N. M. Mahmoodi, and N. S. Tabrizi, "Removal of dyes from colored textile wastewater by orange peel adsorbent: equilibrium and kinetic studies," Journal of Colloid and interface Science, vol. 288, no. 2, pp. 371-376, 2005.

[66] U. Kumar and M. Bandyopadhyay, "Sorption of cadmium from aqueous solution using pretreated rice husk," Bioresource technology, vol. 97, no. 1, pp. 104-109, 2006.

[67] K. Y. Foo and B. H. Hameed, "Insights into the modeling of adsorption isotherm systems," Chemical engineering journal, vol. 156, no. 1, pp. 2-10, 2010.

[68] L. A. Rodrigues, M. L. C. P. da Silva, M. O. Alvarez-Mendes, A. dos Reis Coutinho, and G. P. Thim, "Phenol removal from aqueous solution by activated carbon produced from avocado kernel seeds," Chemical Engineering Journal, vol. 174, no. 1, pp. 49-57, 2011.

[69] Z. Bekçi, Y. Seki, and M. K. Yurdakoç, "Equilibrium studies for trimethoprim adsorption on montmorillonite KSF," Journal of Hazardous Materials, vol. 133, no. 1-3, pp. 233-242, 2006.

[70] S. Cheng et al., "Adsorption behavior of methylene blue onto waste-derived adsorbent and exhaust gases recycling," RSC advances, vol. 7, no. 44, pp. 27331-27341, 2017.

[71] T. Egbosiuba et al., "Ultrasonic enhanced adsorption of methylene blue onto the optimized surface area of activated carbon: Adsorption isotherm, kinetics and thermodynamics," Chemical Engineering Research and Design, vol. 153, pp. 315-336, 2020.

[72] M. Ncibi et al., "Biosorptive uptake of methylene blue using Mediterranean green alga Enteromorpha spp," Journal of Hazardous Materials, vol. 170, no. 2-3, pp. 1050-1055, 2009. 
[73] E. Daneshvar, A. Vazirzadeh, and A. Bhatnagar, "Biosorption of methylene blue dye onto three different marine macroalgae: Effects of different parameters on isotherm, kinetic and thermodynamic," Iranian Journal of Science and Technology, Transactions A: Science, vol. 43, no. 6, pp. 2743-2754, 2019.

[74] X. Yao et al., "Magnetic activated biochar nanocomposites derived from wakame and its application in methylene blue adsorption," Bioresource Technology, vol. 302, p. 122842, 2020.

[75] N. Sebeia, M. Jabli, A. Ghith, Y. Elghoul, and F. M. Alminderej, "Production of cellulose from Aegagropila Linnaei macro-algae: Chemical modification, characterization and application for the bio-sorptionof cationic and anionic dyes from water," International journal of biological macromolecules, vol. 135, pp. 152-162, 2019.

[76] M. L. F. A. De Castro, M. L. B. Abad, D. A. G. Sumalinog, R. R. M. Abarca, P. Paoprasert, and M. D. G. de Luna, "Adsorption of methylene blue dye and $\mathrm{Cu}$ (II) ions on EDTA-modified bentonite: isotherm, kinetic and thermodynamic studies," Sustainable Environment Research, vol. 28, no. 5, pp. 197-205, 2018.

[77] L. Zeghoud, M. Gouamid, O. B. Mya, A. Rebiai, and M. Saidi, "Adsorption of methylene blue dye from aqueous solutions using two different parts of palm tree: palm frond base and palm leaflets," Water, Air, \& Soil Pollution, vol. 230, no. 8, p. 195, 2019.

[78] D. Caparkaya and L. Cavas, "Biosorption of Methylene Blue by a Brown Alga Cystoseira barbatula Kützing," Acta Chimica Slovenica, vol. 55, no. 3, 2008.

[79] J. Y. Chin, L. M. Chng, S. S. Leong, S. P. Yeap, N. H. M. Yasin, and P. Y. Toh, "Removal of Synthetic Dye by Chlorella vulgaris Microalgae as Natural Adsorbent," ARABIAN JOURNAL FOR SCIENCE AND ENGINEERING, 2020.

[80] T. Santhi, S. Manonmani, V. Vasantha, and Y. Chang, "A new alternative adsorbent for the removal of cationic dyes from aqueous solution," Arabian journal of chemistry, vol. 9, pp. S466-S474, 2016.

[81] T. S. Chandra et al., "Defatted algal biomass as a non-conventional low-cost adsorbent: surface characterization and methylene blue adsorption characteristics," Bioresource technology, vol. 184, pp. 395404, 2015.

[82] M. C. Ncibi, B. Mahjoub, and M. Seffen, "Kinetic and equilibrium studies of methylene blue biosorption by Posidonia oceanica (L.) fibres," Journal of hazardous materials, vol. 139, no. 2, pp. 280-285, 2007.

[83] S. Cengiz and L. Cavas, "Removal of methylene blue by invasive marine seaweed: Caulerpa racemosa var. cylindracea," Bioresource Technology, vol. 99, no. 7, pp. 2357-2363, 2008.

[84] D. Sallet et al., "Ultrasound-assisted extraction of lipids from Mortierella isabellina," Journal of Food Engineering, vol. 242, pp. 1-7, 2019.

[85] E. G. Bligh and W. J. Dyer, "A rapid method of total lipid extraction and purification," Canadian journal of biochemistry and physiology, vol. 37, no. 8, pp. 911-917, 1959.

[86] A. V. Rane, K. Kanny, V. Abitha, and S. Thomas, "Methods for synthesis of nanoparticles and fabrication of nanocomposites," in Synthesis of inorganic nanomaterials: Elsevier, 2018, pp. 121-139.

[87] D. Ramimoghadam, S. Bagheri, and S. B. Abd Hamid, "Progress in electrochemical synthesis of magnetic iron oxide nanoparticles," Journal of Magnetism and Magnetic Materials, vol. 368, pp. 207-229, 2014. 
[88] T. Nematian, Z. Salehi, and A. Shakeri, "Conversion of bio-oil extracted from Chlorella vulgaris micro algae to biodiesel via modified superparamagnetic nano-biocatalyst," Renewable Energy, vol. 146, pp. 1796-1804, 2020.

[89] L. D. Youcef, L. S. Belaroui, and A. López-Galindo, "Adsorption of a cationic methylene blue dye on an Algerian palygorskite," Applied Clay Science, vol. 179, p. 105145, 2019.

[90] M. A. Bezerra, R. E. Santelli, E. P. Oliveira, L. S. Villar, and L. A. Escaleira, "Response surface methodology (RSM) as a tool for optimization in analytical chemistry," Talanta, vol. 76, no. 5, pp. 965-977, 2008.

[91] Y.-S. Ho and G. McKay, "Pseudo-second order model for sorption processes," Process biochemistry, vol. 34, no. 5, pp. 451-465, 1999.

[92] F.-C. Wu, R.-L. Tseng, and R.-S. Juang, "Initial behavior of intraparticle diffusion model used in the description of adsorption kinetics," Chemical engineering journal, vol. 153, no. 1-3, pp. 1-8, 2009.

[93] G. Roberts, Langmuir-blodgett films. Springer Science \& Business Media, 2013.

[94] Y. Cui, A. Masud, N. Aich, and J. D. Atkinson, "Phenol and Cr (VI) removal using materials derived from harmful algal bloom biomass: Characterization and performance assessment for a biosorbent, a porous carbon, and Fe/C composites," Journal of hazardous materials, vol. 368, pp. 477-486, 2019.

[95] I. Langmuir, "The constitution and fundamental properties of solids and liquids. Part I. Solids," Journal of the American chemical society, vol. 38, no. 11, pp. 2221-2295, 1916.

[96] H. Freundlich, "Over the adsorption in solution," J. Phys. Chem, vol. 57, no. 385471, pp. 1100-1107, 1906.

[97] M. Tempkin and V. Pyzhev, "Kinetics of ammonia synthesis on promoted iron catalyst," Acta Phys. Chim. USSR, vol. 12, no. 1, p. 327, 1940.

[98] R. Aravindhan, J. R. Rao, and B. U. Nair, "Removal of basic yellow dye from aqueous solution by sorption on green alga Caulerpa scalpelliformis," Journal of Hazardous Materials, vol. 142, no. 1-2, pp. 68-76, 2007.

[99] H. N. Tran, S.-J. You, A. Hosseini-Bandegharaei, and H.-P. Chao, "Mistakes and inconsistencies regarding adsorption of contaminants from aqueous solutions: a critical review," Water research, vol. 120, pp. 88-116, 2017. 
Figures

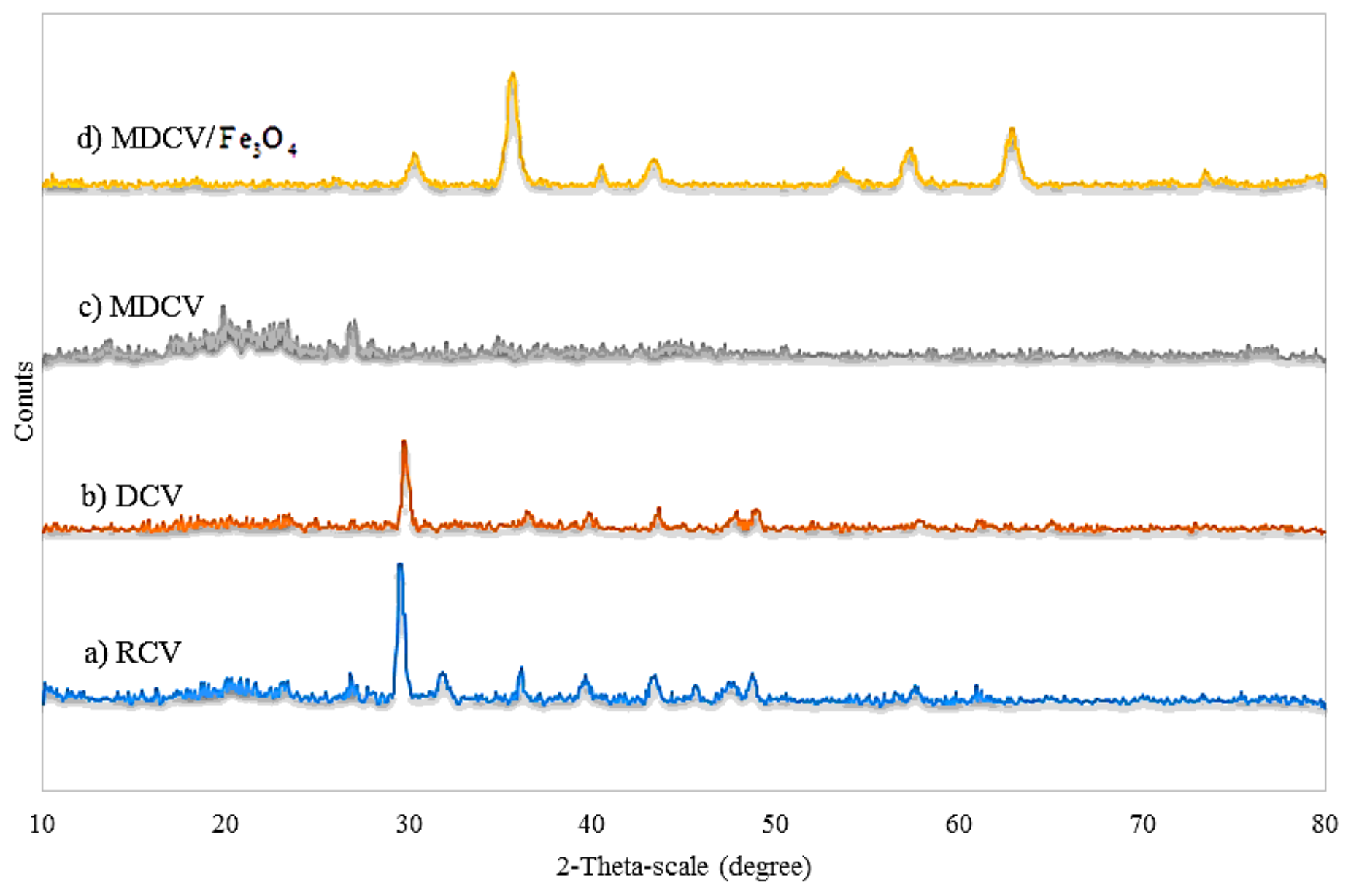

Figure 1

XRD analysis for a) RCV, b) DCV, c) MDCV and d) MDCV/Fe304 


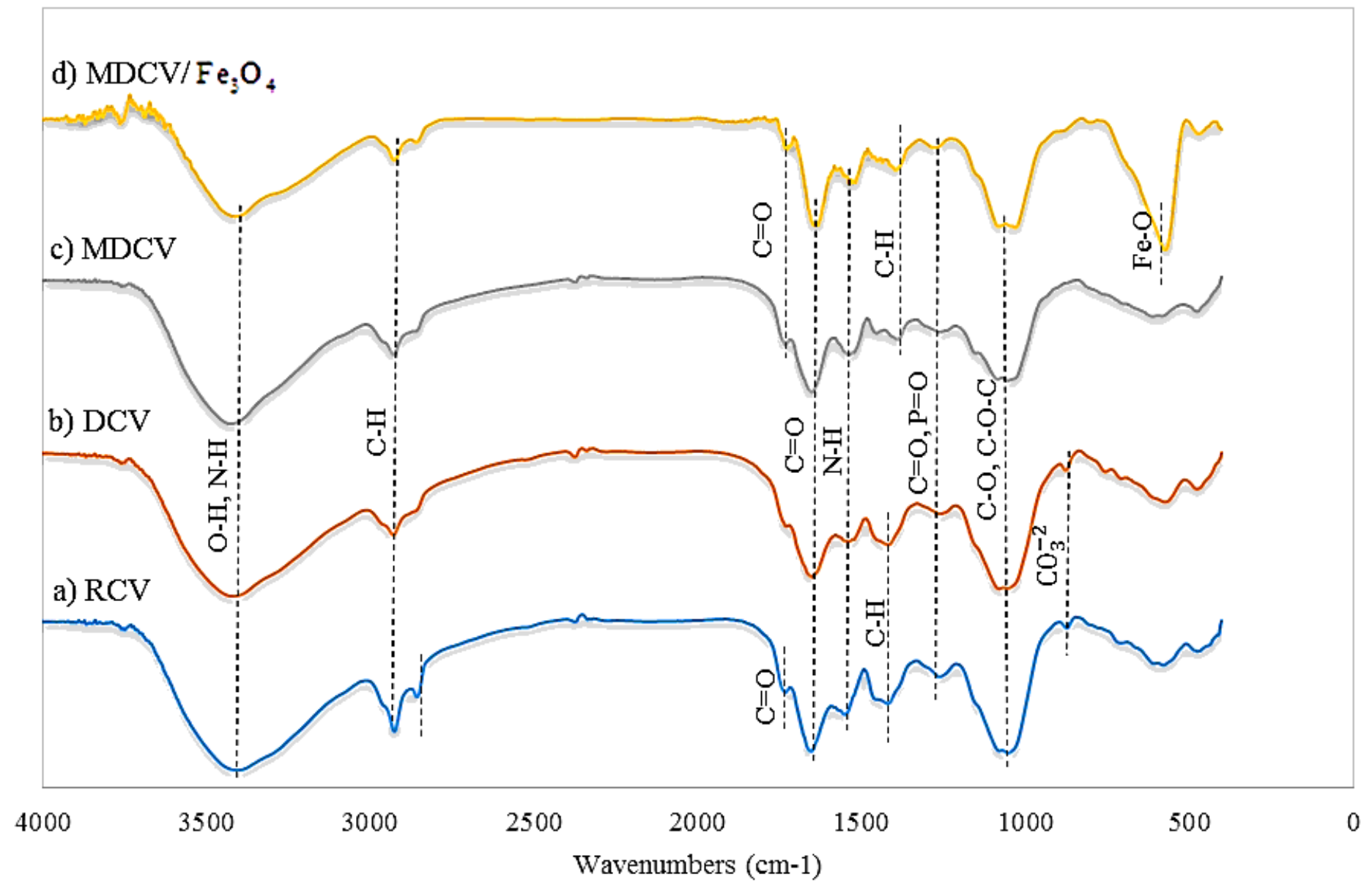

Figure 2

FT-IR analysis for a) RCV, b) DCV, c) MDCV, and d) MDCV/Fe304 


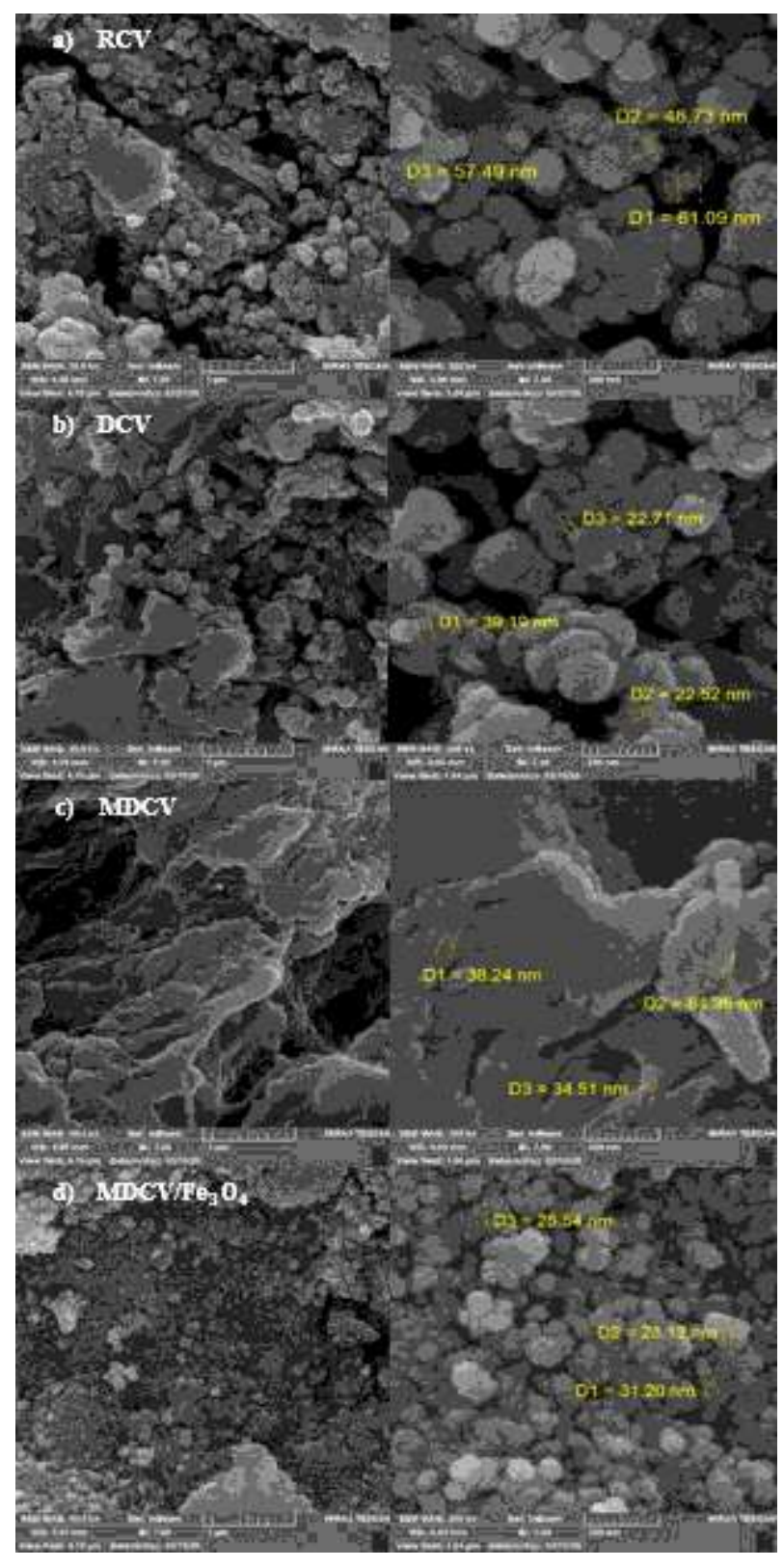

Figure 3

SEM analysis for a) RCV, b) DCV, c) MDCV, and d) MDCV/Fe304 

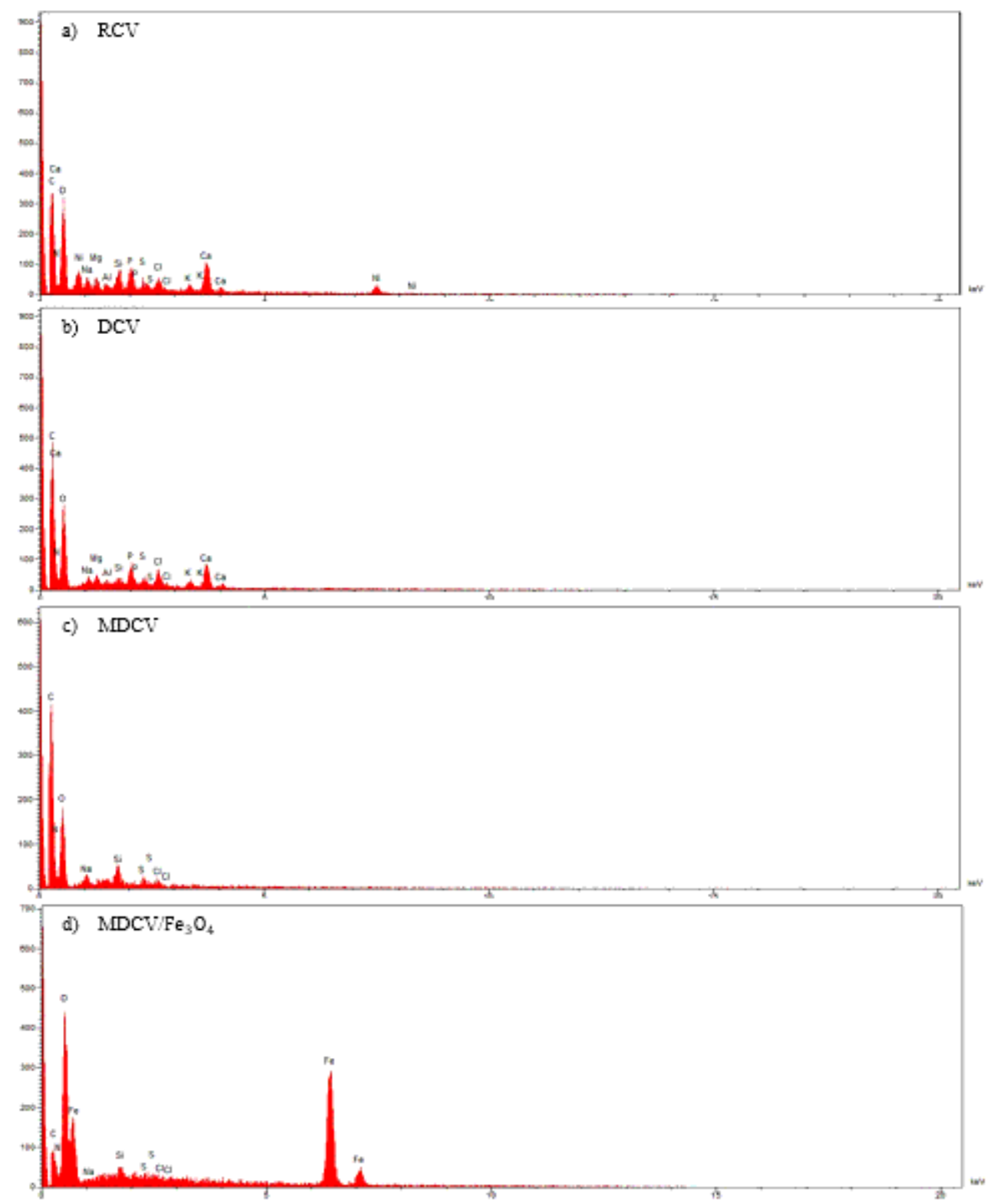

Figure 4

EDS analysis for a) RCV, b) DCV, c) MDCV, and d) MDCV/Fe304 

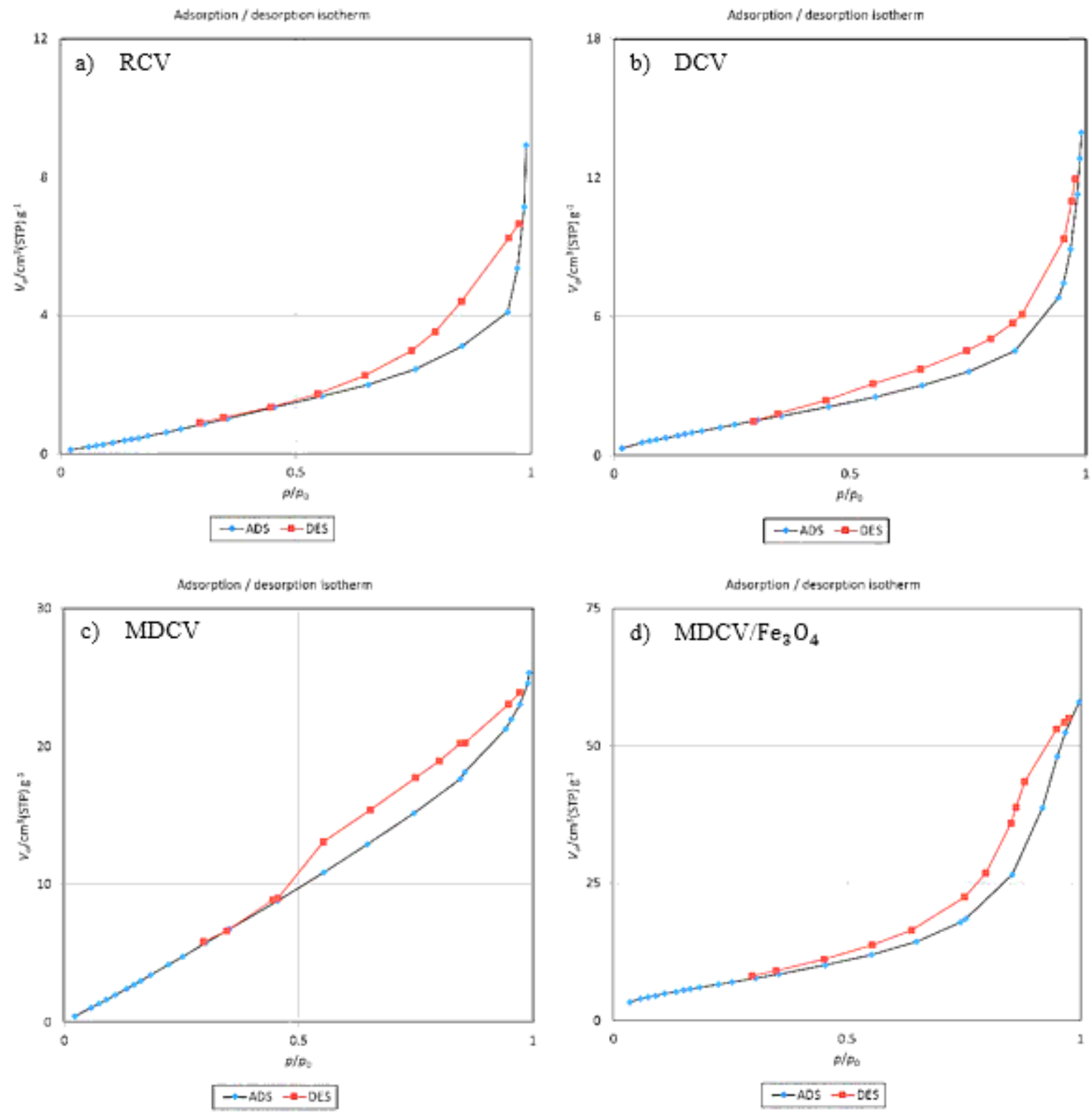

Figure 5

Nitrogen adsorption-desorption isotherm for a) RCV, b) DCV, c) MDCV, and d) MDCV/Fe304 

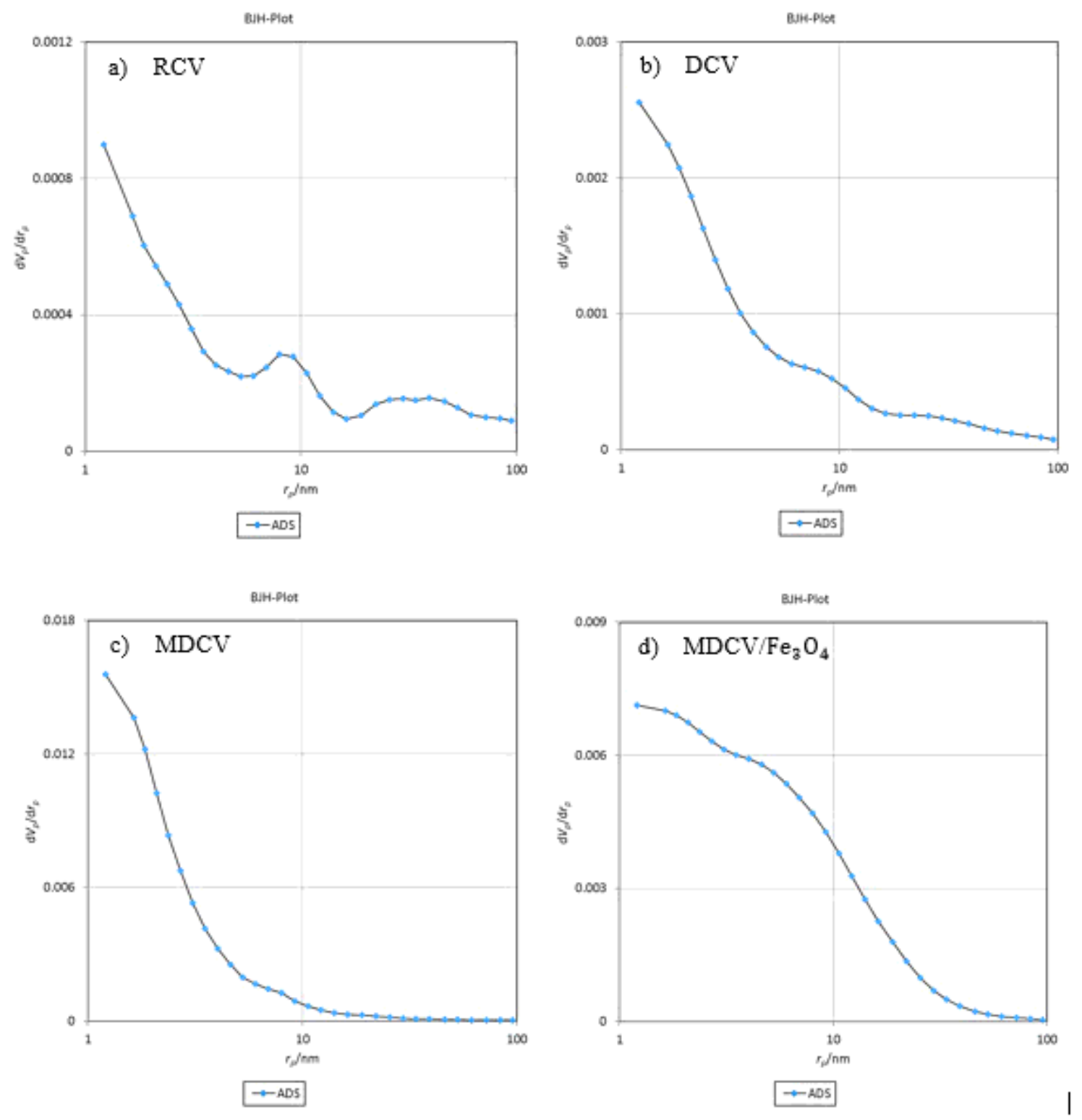

Figure 6

BJH pore size distribution for a) RCV, b) DCV, c) MDCV, and d) MDCV/Fe304 


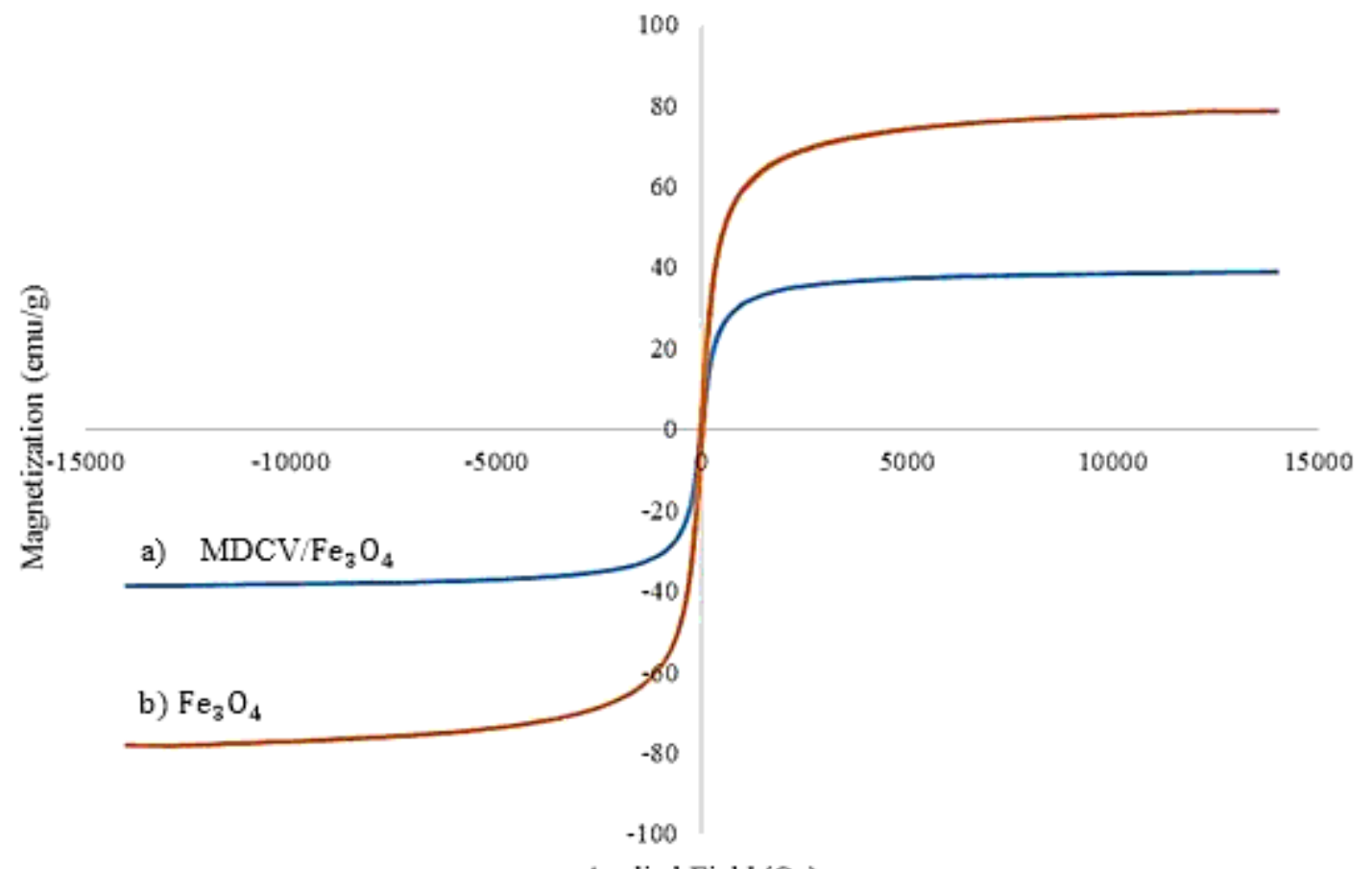

Applied Field (Oe)

Figure 7

VSM analysis for a) MDCV/Fe_3 O_4, b) Fe304 

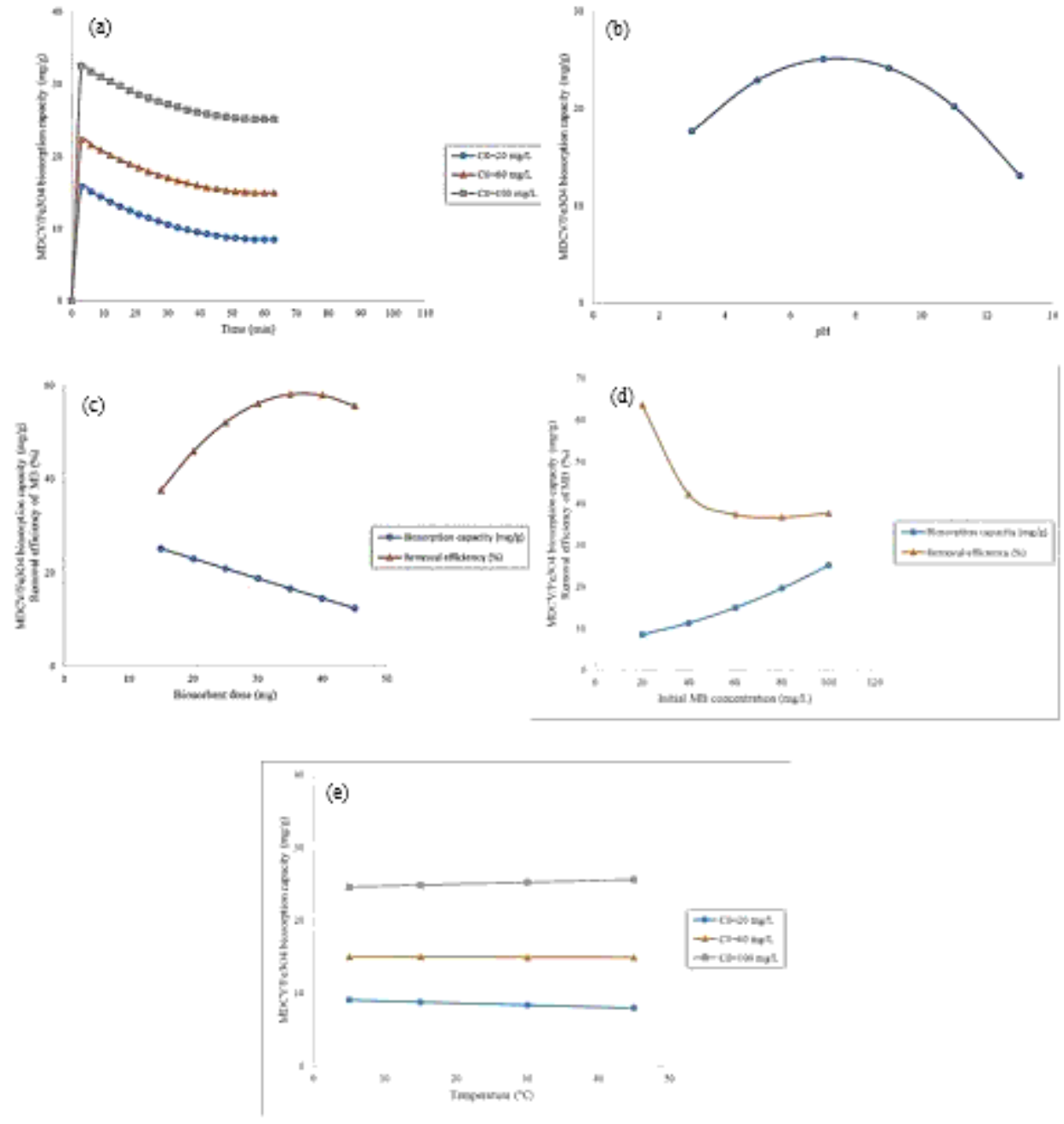

\section{Figure 8}

Effect of a) contact time ( $T=25 \rrbracket, m=15 \mathrm{mg}, \mathrm{pH}=7), \mathrm{b}) \mathrm{pH}(\mathrm{T}=25 \mathrm{\textrm {N }}, \mathrm{t}=60 \mathrm{~min}, \mathrm{~m}=15 \mathrm{mg}, \mathrm{CO}=100 \mathrm{mg} / \mathrm{L}), \mathrm{c})$ biosorbent dosage $(T=25 \bigotimes, t=60 \mathrm{~min}, \mathrm{C} 0=100 \mathrm{mg} / \mathrm{L}, \mathrm{pH}=7), d)$ initial concentration of $M B(T=25 \bigotimes, t=60$ min, $m=15 \mathrm{mg}, \mathrm{pH}=7)$, and e) temperature ( $\mathrm{t}=60 \mathrm{~min}, \mathrm{~m}=15 \mathrm{mg}, \mathrm{pH}=7)$ on biosorption of $\mathrm{MB}$ by $\mathrm{MDCV} / \mathrm{Fe} 304$ 

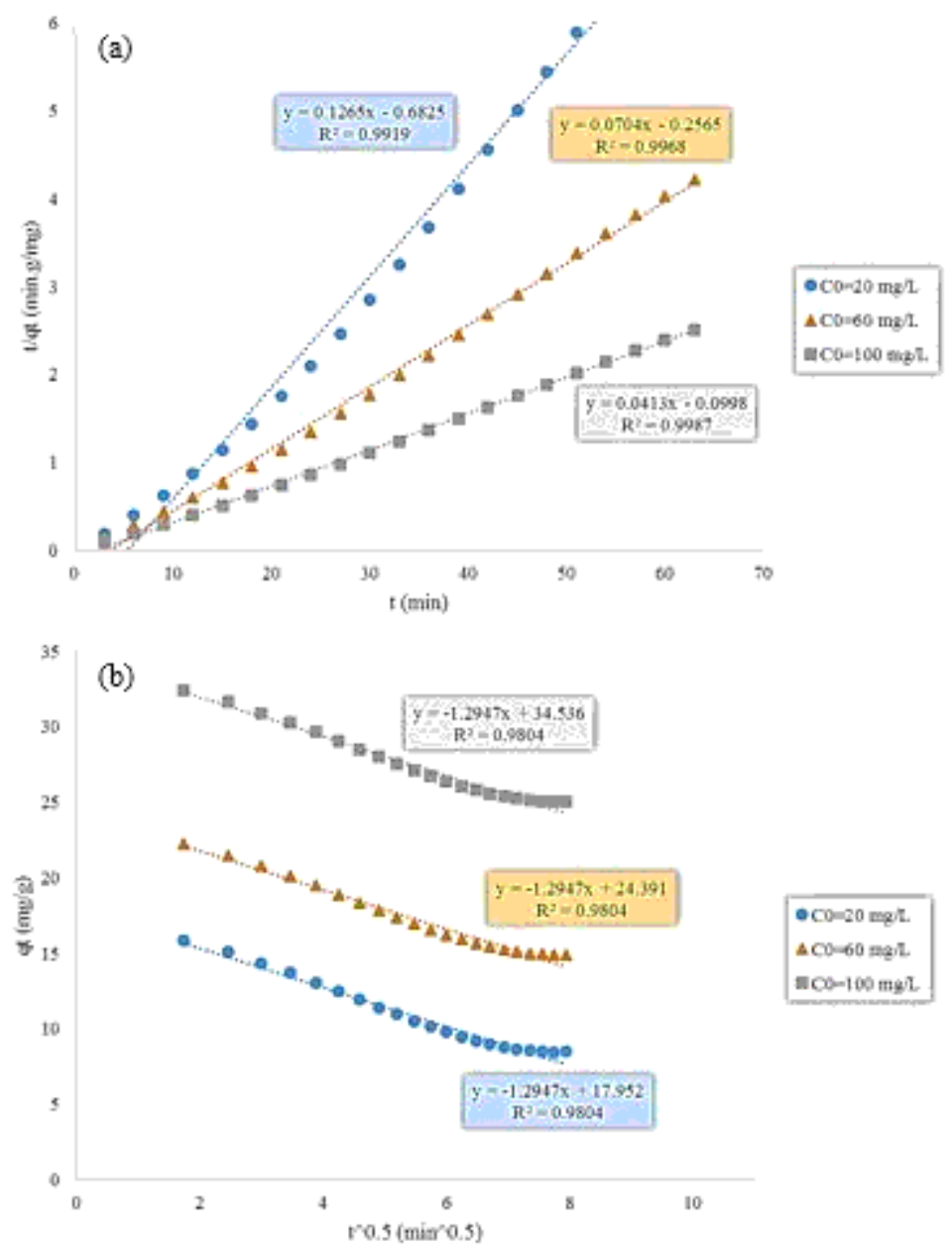

\section{Figure 9}

Plots of a) pseudo-second-order, b) intraparticle diffusion kinetic models for MB biosorption onto $\mathrm{MDCV} / \mathrm{Fe} 304(\mathrm{~T}=25 \rrbracket, \mathrm{m}=15 \mathrm{mg}, \mathrm{pH}=7$ ) 

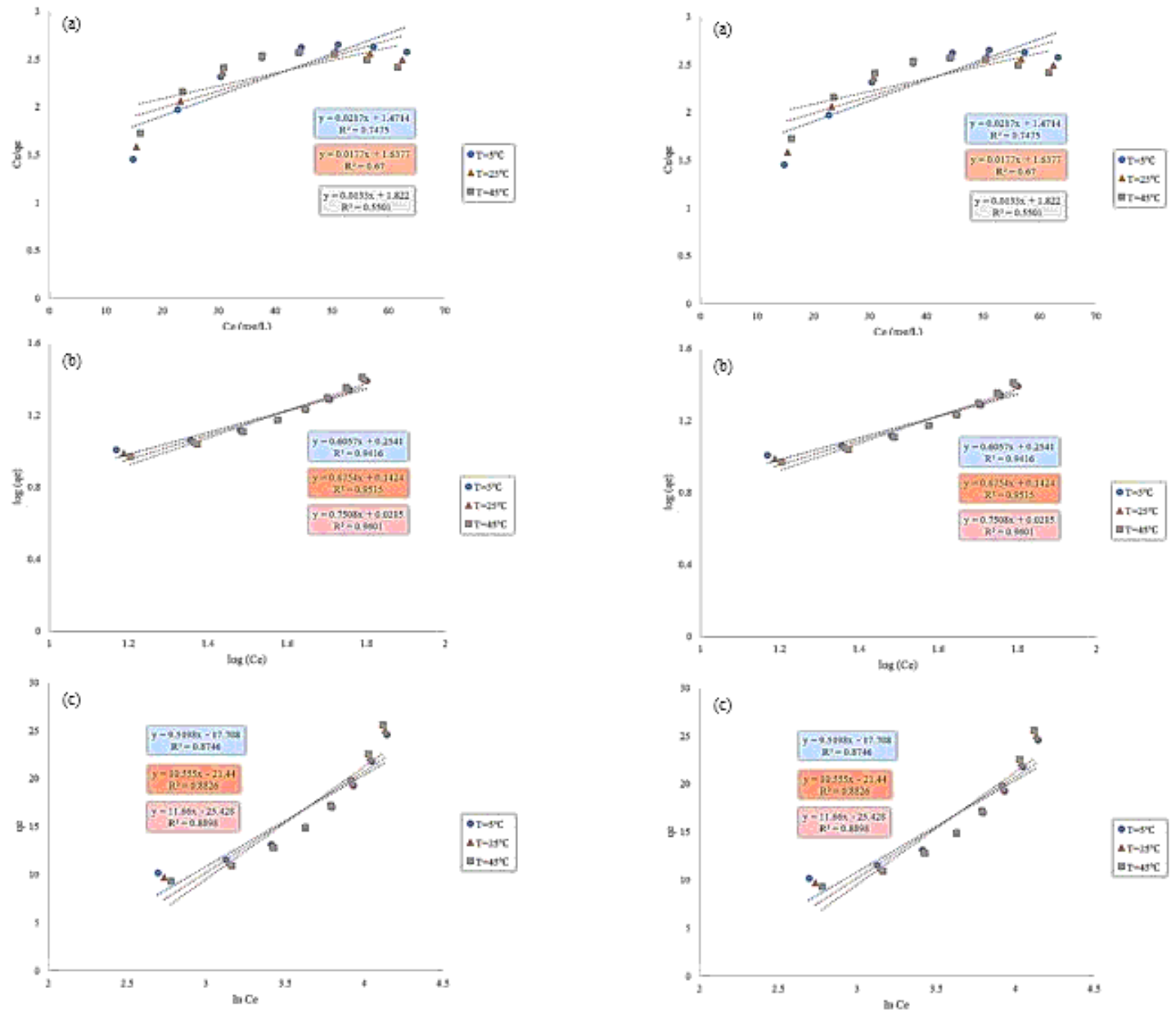

Figure 10

Plots of a) Langmuir, b) Freundlich, c) Temkin isotherm models for MB biosorption onto MDCV/Fe304 


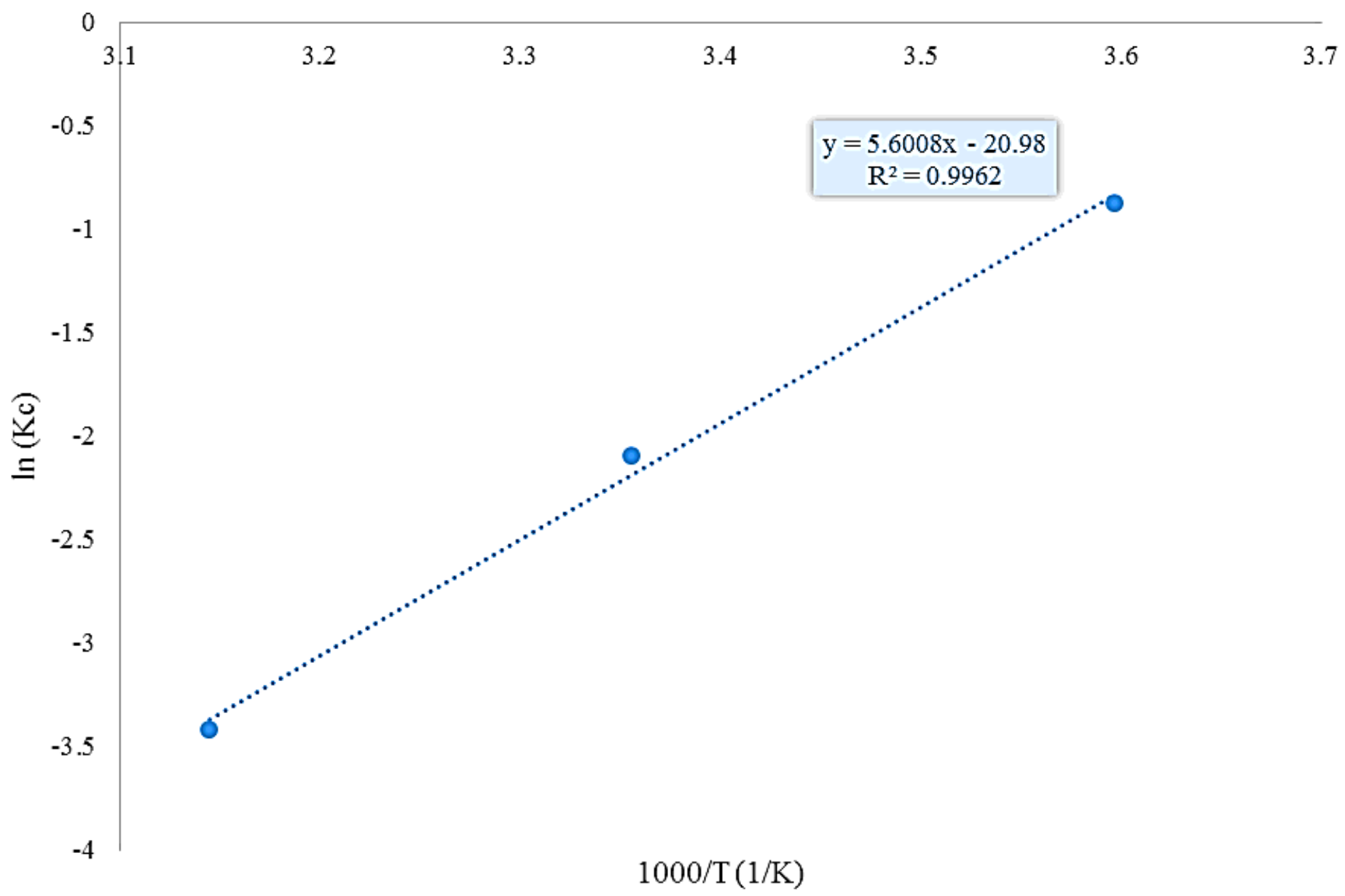

Figure 11

Van't Hoff diagram for the estimation of thermodynamic parameters 